\title{
Political realignment of British Jews: Testing competing explanations
}

DOI:

10.1016/j.electstud.2019.102063

\section{Document Version}

Accepted author manuscript

Link to publication record in Manchester Research Explorer

\section{Citation for published version (APA):}

Barclay, A., Sobolewska, M., \& Ford, R. (2019). Political realignment of British Jews: Testing competing explanations. Electoral Studies, 61. https://doi.org/10.1016/j.electstud.2019.102063

\section{Published in:}

Electoral Studies

\section{Citing this paper}

Please note that where the full-text provided on Manchester Research Explorer is the Author Accepted Manuscript or Proof version this may differ from the final Published version. If citing, it is advised that you check and use the publisher's definitive version.

\section{General rights}

Copyright and moral rights for the publications made accessible in the Research Explorer are retained by the authors and/or other copyright owners and it is a condition of accessing publications that users recognise and abide by the legal requirements associated with these rights.

\section{Takedown policy}

If you believe that this document breaches copyright please refer to the University of Manchester's Takedown Procedures [http://man.ac.uk/04Y6Bo] or contact uml.scholarlycommunications@manchester.ac.uk providing relevant details, so we can investigate your claim.

\section{OPEN ACCESS}




\title{
Political Realignment of British Jews: Testing Competing Explanations.
}

\author{
Andrew Barclay \\ School of Social Sciences, University of Manchester \\ Prof. Maria Sobolewska \\ School of Social Sciences, University of Manchester \\ Prof. Robert Ford \\ School of Social Sciences, University of Manchester
}

Manuscript accepted for publication by Electoral Studies

How to cite:

Barclay, Andrew. Sobolewska, Maria. \& Ford, Robert (2019) "Political Realignment of British Jews:

Testing Competing Explanations" Electoral Studies, 61 


\title{
Political realignment of British Jews: testing competing explanations.
}

\begin{abstract}
$\underline{\text { Abstract }}$
This paper shows that the historical association of the British Jewish community with the Labour party is a thing of the past, and that a large majority now support the Conservatives. We test competing explanations for this realignment; (i) socio-economic progression, (ii) that perceptions of anti-Jewish discrimination no longer align British Jews with Labour given recent antisemitism scandals, and finally (iii) perceptions of Labour leader Jeremy Corbyn, who many identify as personally responsible for failing to address and even tacitly embracing antisemitism within Labour. We find evidence that Jewish voters identify a lot more as middle class and that they do not believe that antisemitic prejudice holds them back in society. Both of these factors make Labour less appealing to Jews than is the case for other minority groups. We also find that Jeremy Corbyn is disliked by Jews more than non-Jews, irrespective of how they feel towards Labour generally.
\end{abstract}

\section{Introduction}

The question of the political preferences of Jewish voters in Britain is an interesting one. Typically, immigrant-origin ethnic minority groups in Britain have overwhelmingly supported the Labour Party (Saggar 1992, Heath et al 2013). Indeed, evidence from Jewish communities in other Western democracies show that Jewish voters are for the most part either left of centre or moderate in their partisan choices (Wald 2016, Sonenshein \& Valentino 2000, Kotler-Berkowitz 2000, Smith \& Martinez 2017, Schnapper et al 2010, LaPonce 1988). Yet, unlike other immigrant-origin minorities in Britain, existing evidence suggests that the partisan attachments of British Jews are divided. Kotler-Berkowitz $(2001,2002)$ shows internal divisions of party support in a number of areas. He finds that stronger ethnic identity is related to a greater likelihood of voting Conservative, in contrast to most other ethno-religious minorities in Britain (Heath et al 2013). However, more recent developments suggest that this is not a satisfactory account of contemporary Jewish politics. Whilst research from The Institute of Jewish Policy Research (JPR April 2010) suggests that Jews were evenly split in their partisan attachment to the two main parties ahead of the 2010 election, analysis of Jewish respondents using the 2010 British Election Study (Clements \& Spencer 2014) shows a stronger skew to the Conservatives than either the JPR or 
Kotler Berkowitz' research would suggest. ${ }^{1}$ This claim is supported by recent polls of the Jewish population (The Jewish Chronicle 2015, 2016, 2017).

If the political preferences of modern Anglo-Jewry today are diverse and if anything, Conservative leaning, then this has not always been the case. There have traditionally been linkages between Britain's Jewish population and the progressive side of British politics: first the Liberals and then later with the Labour Party (Alderman 1983). Such linkages are unsurprising given what we know about both the Jewish population and the parties during this period. The majority of first and second generation immigrants (forming approximately $75 \%$ of the Jewish population at the time) were overwhelmingly from Labour leaning socio-economic groups, and were heavily concentrated in urban areas where Labour were strong, particularly in East London, Manchester, Leeds and Glasgow (Alderman 1975, 1983). Moreover, the Conservatives had a history of taking positions seen as hostile to Jewish concerns, including longstanding opposition to allowing Jews to obtain legal equality throughout the $19^{\text {th }}$ century, opposition to accepting Jewish refugees fleeing pogroms in Russia, and a general tolerance of antisemitic attitudes and behaviour within their ranks (Alderman, 1983). Within this context, it is not surprising that the large majority of Anglo-Jewry felt more at home on the left (Alderman 1983).

In this way, Jews initially seemed just like other immigrant origin communities in Britain, who have generally aligned with the left. Labour have long been strongly supported as the prominority and anti-racist options by migrant origin ethnic minority voters (Saggar 2004, Heath et al 2014). Much of the British literature focuses on racial minorities, but an analysis of Irish voters suggests that this pattern holds also for this white migrant origin religious minority (Tilley 2015). This pattern is repeated in most other western democracies (Dancygier \& Saunders 2006, Maxwell 2012, Tate 1994, Dawson 1994), so we might expect that migrant-origin minority status might encourage a similar alignment with the left among British Jews. Comparing Jewish political preferences with those of other ethno-religious minorities' politics is therefore of particular theoretical interest as it helps ascertain whether there is truly a distinctive and generalisable phenomenon of migration origin ethnic and religious minority alignment with the political left.

This early account of British Jews being aligned with the left has been challenged in recent years. There are three theories for a potential weakening of Jewish support for Labour, and it is the purpose of this paper to test the evidence for each of them. The first is a structural theory: the social and economic advancement of British Jews means they now disproportionately

\footnotetext{
${ }^{1}$ The results for the 2010 BES are based on an unweighted sample with $n=130$ cases, thereby reducing the statistical power of this claim
} 
hold demographic characteristics typically associated with Conservative support. The second is that minority voters share a sense of linked fate (Dawson 1994) with other members of their group and that Labour is no longer a party seen as representing or advancing the interests of British Jews as a group The third theory is that, following the election Jeremy Corbyn as Labour leader in 2015, the Labour leadership has become seen as hostile towards Britain's Jewish community, or at least tolerant of those who express hostility to Jews. We will consider each of these three explanations in turn, starting with a discussion of existing evidence on each theory in the next section.

\section{Existing literature on Jewish party preference in Britain}

The socio-economic profile of Anglo-Jewry has changed dramatically in a few generations, with upward mobility shifting their profile towards privileged groups who typically support for the Conservatives. Jewish voters are now disproportionately found within the professional social classes (Alderman 1992); they are also much more likely to be self-employed (Graham et al 2007), another economic class traditionally been associated with Conservative support (Heath et al 1991, Evans \& Mellon 2016). A large proportion of British Jews now live in more affluent suburban constituencies (Boyd 2015) where the Conservatives are often locally dominant. Taken together with a significantly older age skew (Graham 2013), this provides a set of sound demographic reasons for Jews to lean Conservative.

There are examples of Jewish communities leaning to the right, notably in South Africa (Kotler-Berkowitz 2002) and despite until recently being associated with the left, Canada (Medved 2013), but the large Jewish community in the US has not followed this path. American Jews have remained consistently more liberal and supportive of the Democrats than the wider US electorate despite economic and social advancement (Wald 2016, Sonenshein \& Valentino 2000, Kotler-Berkowitz 2000) This alignment shows no sign of weakening, with over $70 \%$ of US Jews voting for Hillary Clinton in 2016 (Smith \& Martinez 2017).

This persistent alignment with left voting despite socio-economic advancement aligns American Jews with other US racial minorities. The mechanism often used to explain American racial minorities' left alignment is "linked fate" (Tate 1994, Dawson 1994), a sense that what happens to the minority group in general affects each group member's life chances, independently from their own individual experience (Dawson 1994). This belief is a lot more politically powerful than simple ethnic group identification (Hwang et al 1998), as it translates 
directly into policy preferences, and hence influences party preferences. British ethnic minorities follow a similar pattern: those who felt that their group was being held back by racial prejudice were a lot less likely to vote for the Conservative party, and more likely to vote Labour (Sanders et al 2014, Heath et al 2013). Ethnic minority voters who do not perceive their fate to be linked to that of their ethnic group are more likely to vote in line with their class and economic interests. In Great Britain, the best example is the British Indian community, who are least worried that discrimination is an issue, and also more likely to vote Conservative than other minorities (Heath et al 2013, Martin 2019).

A similar "linked fate" mechanism may also apply to British Jews. Jewish voters have distinctive political preferences reflecting a greater attention paid to external threats (Medding 1977) to Jews as a group and their political preferences are strongly influenced by how effectively parties oppose such threats. However, the concept of "linked fate" has thus far only been tested on racial minority groups in Britain and US, and the impact of such notions of linked fate on Jewish voters is unknown.

There are two ways in which notions of "linked fate" could explain Anglo-Jewish political behaviour. One the one hand, Jews in Britain may now lean more Conservative if they no longer see sociotropic discrimination against their group as a significant problem, in a similar way to Indian-origin voters. Alternatively, if the Jewish community shares a sense of linked fate just like other minority groups in Great Britain, but uniquely feel that the Labour party is no longer committed to addressing antisemitic prejudice and discrimination, then Jews will face starkly different political incentives to other ethnic minority groups. They may be just as concerned about threats to their security as a group, but take a very different view about which party is best placed to address them. The reasons' Jewish voters' perceptions may be distinctive on this front relate to the main British parties' approaches to Middle Eastern politics, and their record on antisemitism.

Historically, as we have seen, Labour has been the more responsive party to minority groups and their concerns about discrimination, including migrant Jewish communities. The Conservatives, by contrast opposed extending the franchise to Jewish voters, showed a lack of sympathy for the plight of Russian Jewry and for a time resisted creation of Israel (Alderman 1983) but also showed an apparent indifference to instances of antisemitism within their ranks (Philpot 2017). However, the election of Margaret Thatcher as party leader signalled a significant shift in both presentation and policy. Rhetorically, Thatcher espoused the virtue of JudeoChristian' values and built strong relationship with the Chief Rabbi, Immanuel Jakobovits 
(Philpot 2017). The number of Jewish MPs on the Tory benches rose significantly to their highest ever number during her tenure, with many being promoted to high office during the Thatcher and Major Governments. At one stage more than a quarter of the Cabinet were Jewish MPs, and in Nigel Lawson (Treasury), Leon Brittan and Michael Howard (Home Office) and Malcolm Rifkind (Foreign Office), the three great offices of state were held by Jewish MP during these Conservative governments. Mrs Thatcher also offered steadfast support to Israel in contrast to her predecessor Ted Heath, who was perceived as taking the side of the Arab states during the Yom-Kippur War (Philpot 2017).

The Labour party had historically been perceived as steadfast champions of Israel and Zionism in British politics, albeit with some vocal and prominent critics (Alderman 1983, Keleman 2000, Philpot 2017). At the same time however, an 'anti-Zionist' movement began to gain ground within the New Left grassroots from the 1960s onwards. The anti-Zionists viewed Zionism as less the expression of self-determination of the Jewish people, and more of a Western colonial project similar to Apartheid South Africa (Bolton \& Pitts 2018, Rich 2016, 2018), a position which puts them at odds with the overwhelming majority of Jewish voters who define as Zionist in some way (Graham \& Boyd 2010, Miller et al 2015). ${ }^{2}$ Foreign policy issues of particular salience to the Jewish community relating to the politics of Zionism, Israel and the Middle East have been cited as influential on the political choices of Jews (Alderman 2011). Should we expect linked fate to be a driving factor in the political choices of Jews, then the positions of the two main parties would lead us to expect greater levels of support for the Conservatives on this basis.

Despite the growing popularity of 'anti-Zionist' perspectives in the broader left over recent decades, its main manifestations - anti-Israeli boycotts, conference motions and antiIsrael rhetoric - were until recently confined to the fringes of the activist left, and enjoyed little support within the Parliamentary Labour party and certainly not the party leadership ${ }^{3}$. The election of Jeremy Corbyn, a prominent and vocal supporter of the anti-Zionist movement, as Labour party leader therefore marks a watershed moment and offers a third explanation for Jewish realignment. Under Cobyn's leadership Labour has been plagued by frequent and widely

\footnotetext{
${ }^{2}$ This is whilst recognising the broad diversity of opinion regarding the preferred foreign and domestic policy direction of the Israeli Government, as Miller et al (2015) show. Nevertheless, the baseline principle of supporting the existence of Israel, and its centrality to Jewish identity, has near universal agreement. ${ }^{3}$ A notable and controversial exception was Mayor of London Ken Livingstone (Alderman, 2012), whose vocal and longstanding espousal of anti-Zionist arguments eventually led to his suspension and then departure from the Labour party
} 
reported allegations of antisemitism by party members, officials, candidates and supporters and the leadership's responses to these scandals have been widely criticised as weak and indecisive.

The first high profile controversy was the resignation of a co-chair of Oxford University Labour Club in February 2016, citing a hostile, anti-Jewish organisational culture (The Guardian February 17 2016). Since then, a series of similar controversies have erupted involving Labour activists and members promoting antisemitic ideas and arguments (Rich 2016, 2018). Such controversies were no longer limited to the left's activist base, with the Bradford West Labour MP Naz Shah being temporarily suspended by Labour due to a series of online posts comparing Israel to, amongst other things, Apartheid South Africa and Nazi Germany (The Guardian April 27 2016). The most significant recurring element in these stories has been the response from the party leadership in general and Jeremy Corbyn in particular. As a longstanding supporter of the Palestine Solidarity Campaign and former patron of the Stop the War coalition, his anti-Israeli approach to the politics of the Middle East are well documented (Rich 2016, 2018), including his previous referral to members of Hamas and Hezbollah as 'friends' (Hirsh 2017). It is unprecedented for a Labour politician of Corbyn's seniority to hold such views publically, and it has led to frequent and very critical scrutiny of the party leadership's response to expressions of hostility to the Jewish community and its concerns, which can no longer be regarded as a fringe stance within the Party.

An inquiry into 'antisemitism and other forms of racism' within the Labour party, conducted by Shami Chakrabarti was widely criticised as an insubstantial response to this problem. ${ }^{4}$ The report was criticised for failing to recognise how institutional hostility towards Israel manifested itself through antisemitic positions (Rich 2018, Hirsh 2017) and was dismissed by the Board of Deputies of British Jews as a 'whitewash' (The Times of Israel Oct $7^{\text {th }} 2016$, The Jewish Chronicle July $6^{\text {th }} 2016$ ) in stark contrast to a House of Commons Select Committee report on antisemitism, which found that Labour had a significant case to answer (House of Commons Report 2016). Indeed, even the launch event for the report was marred by accusations of antisemitic harassment of the Jewish Labour MP Ruth Smeeth (New Statesman Jun 30 ${ }^{\text {th }} 2016$ ) by an activist with links to the Labour leadership (Rich 2018, Hirsh 2017). These controversies have shown no sign of abating since; two (now former) Labour MPs of Jewish heritage, Luciana Berger and Ian Austin have resigned from the party, both citing an antisemitic culture allowed to grow under Corbyn's leadership as a key reason (following suggestions of antisemitic bullying from local activists in the case of Berger; The Guardian February 10 $0^{\text {th }} 2019$, The Guardian February

\footnotetext{
${ }^{4}$ See Hirsh (2017) for a full review
} 
$\left.22^{\text {nd }} 2019\right)$. As a result, as well as the party being at risk of alienating Jewish voters, we also must consider the role of the leader as a significant contributing factor.

Cumulatively, we have a range of competing explanations which could explain any distinctive character to the party support of British Jews; demographic change, linked fate with their co-religionists and the trajectory of the Labour party under the leadership of Jeremy Corbyn. It is the focus of the rest of this paper to test these varying explanations. Based on these distinct possibilities we propose to test the following hypotheses:

H1. Structural voting: The demography of British Jews largely accounts for their Conservative leanings;

H2. Linked fate: Similar to other minorities, Jewish voters display a high sense of linked fate (H2i) but also believe that Labour is no longer the party best placed to address these concerns, therefore their sense of linked fate will account for Conservative preference (H2ii);

H3. Leadership effect: Jeremy Corbyn's record has made him an unacceptable choice for British Jews, and thus limits their option to vote Labour.

\section{Data and Measurement}

Nationally representative surveys in Britain contain only small numbers of Jewish respondents complicating efforts to conduct robust quantitative analysis of Jewish political attitudes. For our analysis, we use a bespoke, cross sectional survey of 512 Jewish voters collated by polling company, Survation in December 2017. Respondents were recruited by a probabilistic assignment of an individual being Jewish based on geographic and demographic characteristics, before randomly selecting respondents and confirming that they identify as Jewish. The panel has been designed to include both practising and non-practising Jews, although sadly we do not have measures of this, and the data are weighted to be representative to the Jewish population as regards age, region and gender. ${ }^{5}$. The survey was conducted predominantly by telephone, with 19 additional respondents completing the survey online.

These data represent a richer and more reliable source than those hitherto available, though it has some limitations. The absence of survey items measuring strength of religious attachment, or denomination within the Jewish faith leaves us unable to investigate variation in

\footnotetext{
${ }^{5}$ More information of Survation's sampling method can be found at https://www.survation.com/wpcontent/uploads/2018/09/Survation-Jewish-Panel-FAQs.pdf
} 
political attitudes on these grounds. This is a significant issue, as historical research suggests religious commitment is associated with Conservative support, that Orthodox Jews in particular have been more likely to support the Conservatives (Kotler-Berkowitz 2001) and that AngloJewry is becoming more Orthodox (Staetsky \& Boyd 2015). As well as this, there are some issues with the measurement of some demographic items, which are detailed below. However, notwithstanding these caveats, this dataset allows analysis of the partisan preferences of Jews of a level of robustness and depth which has previously been unavailable to researchers.

For comparisons with the general population, we have used the British Election Study internet panel (Fieldhouse et al 2018) post 2017 General Election wave, with 31,196 respondents interviewed online by YouGov between $6^{\text {th }}-23^{\text {rd }}$ of June 2017. When making comparisons of perceptions of sociotropic racial discrimination with Britain's non-whites we have used the most recent Ethnic Minority British Election Study Survey (EMBES), a cross-sectional face-to-face survey of 2,787 respondents who self-identify as belonging to an ethnic minority group ${ }^{6}$ conducted between May and August of 2010. For the comparison with the wider white British population on their perceptions of sociotropic racial discrimination, we used a nationally representative study conducted by YouGov online from the $10^{\text {th }}-18^{\text {th }}$ November 2015 with a total sample size of 3,328 (Sniderman, Ford, Sobolewska 2015). The impact of perceptions of racial discrimination on partisan choices is well documented and cited in the above discussion. Rather than replicating these studies, we use these data to show the proportion of non-whites (and the general population) who perceive sociotropic racial prejudice to be a problem, and how this compares to Jews.

Given the limitations of survey data, we also look at aggregate voting patterns in areas with large Jewish communities using three data sources - the 2016 and 2018 "key wards" datasets of local elections results collected for a subset of wards across the country by the team of elections analysts headed by John Curtice for the BBC, and the 2017 general election results dataset constructed for all constituencies by the same team. In each case our goal is to look at patterns of vote change between elections held before and after Jeremy Corbyn became leader of the Labour party. We focus on wards and constituencies where the share of the local Jewish population was above $1 \%$ in the 2011 census, and test the robustness of these relationships to controls for various other demographic predictors of vote choice in these elections, including census measures indicating the proportion of graduates, levels of deprivation and the class and age profile for each ward and constituency. This analysis allows us to add a further test for

\footnotetext{
${ }^{6}$ These groups were Black Caribbean, Black African, Indian, Pakistani and Bangladeshi
} 
changes in Jewish political behaviour following the election of Jeremy Corbyn as Labour leader, complementing the findings of the individual level results.

In our individual level analysis we use propensity to vote for the main parties as our dependent variable. Respondents who indicated that they were possible voters in a future general election were asked which party they were likely to support, being prompted with the Conservatives, Labour, UKIP, the Liberal Democrats, the Greens and any other party as options, as well as undecided and would not vote options. Respondents were then asked to rate their likelihood of ever voting for the main two parties on a 0-10 scale, with 0 being the lowest score.

To measure the socio-demographic profile of respondents we use gender, age, region of residence, highest level of education and self-reported social class. Categories for respondents' region were merged into a dummy variable denoting Jews living in Greater London (1) and the rest of Britain (0) given the very large proportion of British Jews who live in the capital (around two thirds according to the 2001 Census, Abramson et al 2011). Both education level and social class are also operationalised as dummy variables. We separate respondents into graduates (1) and non-graduates $(0)$ given the well documented effect that holding a degree has on social and political attitudes (see for example Surridge 2017). Social class is a self-reported measure, which we recode into 'working class' (0) and 'middle class' (1).

To measure perceptions of linked fate we use a question previously used on the Ethnic Minority British Election Study (EMBES). We include questions measuring perceptions of sociotropic racial prejudice generally and specifically anti-Jewish prejudice. Respondents were asked to rate their agreement with the following statements:

"Non-White people don't have the same opportunities and chances in life as White people, as they are held back by prejudice and discrimination"

"Jewish people in Britain don't have the same opportunities and chances in life as non-Jews, as they are held back by prejudice and discrimination"

Finally, perceptions of party leaders were captured using 11 point like-dislike scales modelled on those employed in the British Election Study (BES). 
We recognise that using assessments of a party's leader as a predictor of party support raises endogeneity issues. The only way to address this is with panel data, which is not available for our cross-sectional sample of Jewish voters. However, we are able to partially address this by using cross-sectional data by looking at (i) the marginal effects predictions of propensity to vote for a party by respondents' perception of its leader, as well as (ii) marginal effects predictions of leader evaluations by their propensity to vote for a party. Whilst not entirely accounting for endogeneity, this approach acts as a more robust test for a 'Corbyn' effect, showing for instance if Jews have a different view of the Labour leader than non-Jews even accounting for propensity to support the party, or if Jews are more likely than non-Jews to vote Conservative even if they are as likely to disapprove of the Conservative leader.

Another way of testing the impact of Jeremy Corbyn's election as party leader in is to use an aggregate-level analysis of voting patterns in areas with large Jewish populations before and after Jeremy Corbyn's election as party leader. While we cannot make confident inferences about individual level change from data, we can make use of it to test whether there is evidence for a distinctive pattern of change in areas with large Jewish communities in the years after Jeremy Corbyn's election as Labour leader. This analysis adds an important longitudinal element to our analysis of the political preferences of British Jews, and is especially useful in triangulating results to identify the effect that Jeremy Corbyn has upon support for Labour.

\section{Results}

\section{Descriptive results}

Table 1 shows the distribution of vote intentions in our sample of Jewish voters. Conservative support is remarkably high at $62 \%$, while only $15 \%$ expressed support for Labour. While Britain's Jewish community may have had Labour leanings in the past, it now shows a strong Conservative lean. 
Table 1 - Voting Intention of British Jews

\begin{tabular}{|l|c|}
\hline & Vote intention (\%) \\
\hline Conservative & 62 \\
\hline Labour & 15 \\
\hline Liberal Democrats & 7 \\
\hline Other & 3 \\
\hline Undecided & 10 \\
\hline Refused & 2 \\
\hline \multicolumn{2}{|l|}{ Note: Jewish Sample n=500 (non-voters removed from sample) } \\
\hline
\end{tabular}

Similarly, using propensity to vote, Figure 1 shows a stark contrast between Anglo-Jewry and the rest of the population, with Jewish voters being much open to voting Conservative (and more likely to reject Labour). Almost two thirds of Jewish respondents (63\%) rate themselves as unlikely to ever vote Labour, some 20 points higher than the British electorate generally. In contrast, around two thirds again (67\%) report being likely or certain to vote for the Conservatives, as opposed to only $22 \%$ who state that they're unlikely to do so. The scale of rejection of Labour is noteworthy, particularly as we don't find this negative view amongst the general population. 


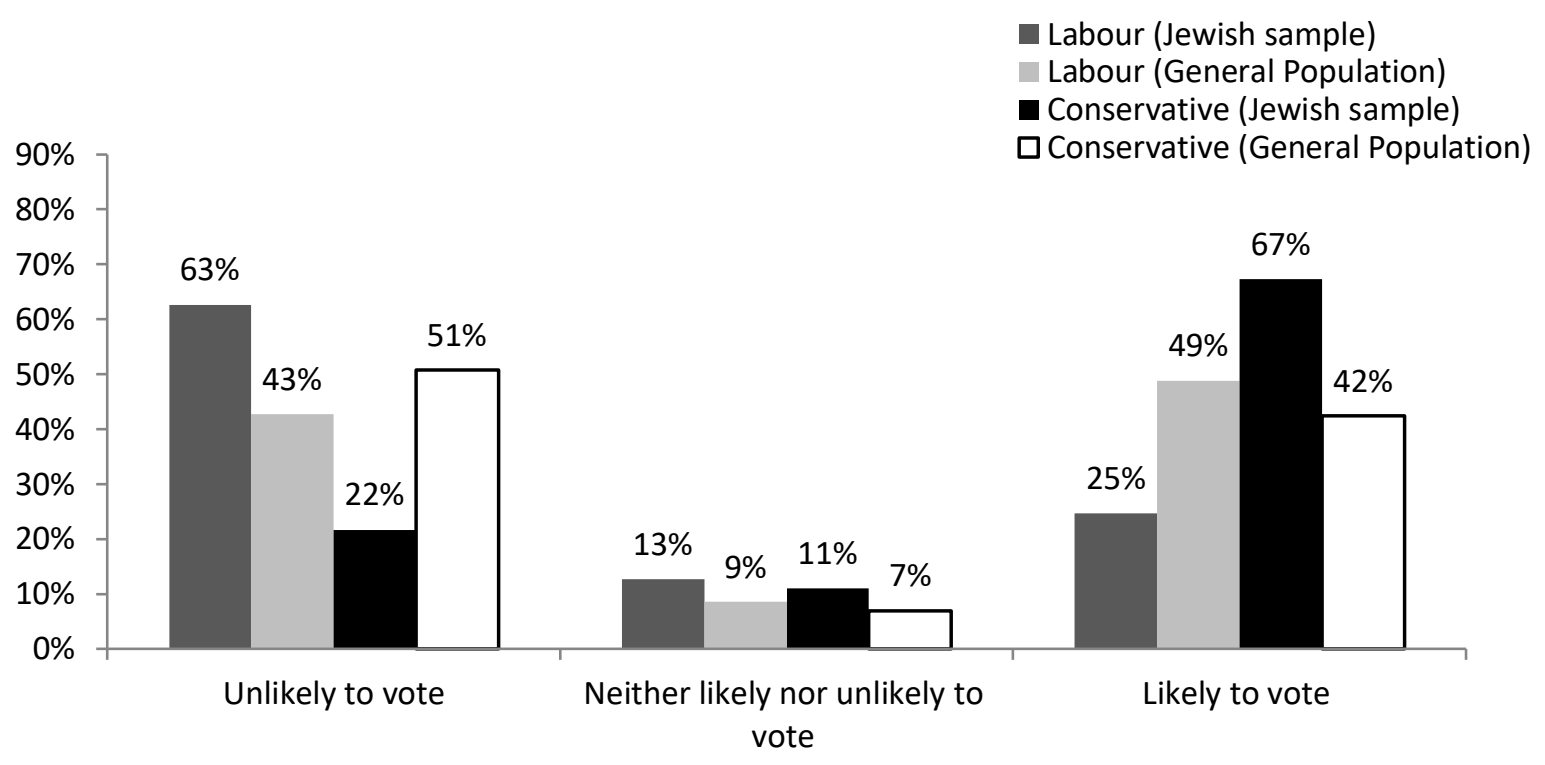

Note: Jewish Sample $n=512$, General Population $n=31,196$

Original 0-10 scale has been recoded into three categories; 0-4 = 'Unlikely to vote', $5=$ 'Neither likely nor unlikely to vote', 6-10 = 'Likely to vote'

0-10 Mean scores for PTV Labour = 4.12 (Jewish Sample) \& 5.10 (General Population). 0-10 Means score for PTV Conservative $=6.72$ (Jewish Sample) \& 4.40 (General Population)

One of the main explanations for this shift to the Conservatives has been changes in the demography of British Jews in a way that would lead us to expect greater levels of attachment to the Tories. To some degree this holds in our sample, particularly regarding age and class identity; $33 \%$ of the total sample post-weighting are 65 or older, almost twice as many as the wider population (ONS 2018) and more respondents self-identify as middle class rather than working class (45\%, full demographic breakdowns not shown here). The effect of demographic composition on party support is tested formally later in the paper, but an explorative look at these characteristics suggests that they may produce patterns of party support which are distinctive from the general population and, at least as far as age and class identity go, in a Conservative direction.

The second hypothesis we test is the notion of linked fate, which we measured by perceptions of sociotropic racial and antisemitic prejudice. In Figure 2 we plot the levels of belief that prejudice holds minority groups back in British society among Jews, non-white Britons, and the general population, as well as belief in the Jewish sample that antisemitism in British society 
holds Jews back. Although a large majority (63\%) of British Jews perceive non-whites to be held back by prejudice, the idea that Jews themselves are held back by the same mechanisms has much less support, with only $16 \%$ of Jews agreeing with this statement. Given that we know that British Jews are an economically successful group in comparative terms, this disparity may in part relate to differences in how antisemitism manifests itself compared to other forms of racism, a point that we address later in the article. Nevertheless, even allowing for this potential difference, the result still indicates that the Jewish conception of linked fate does not map seamlessly onto the concept as it is applied to other ethnic minorities, and that we are in a position already to dismiss hypothesis H2i. However, although sociotropic perceptions of antisemitism are less widespread, it is possible that those who do hold them are more likely to support the Conservatives. 


\section{Figure 2 - Perceptions of Sociotropic Racial Discrimination}

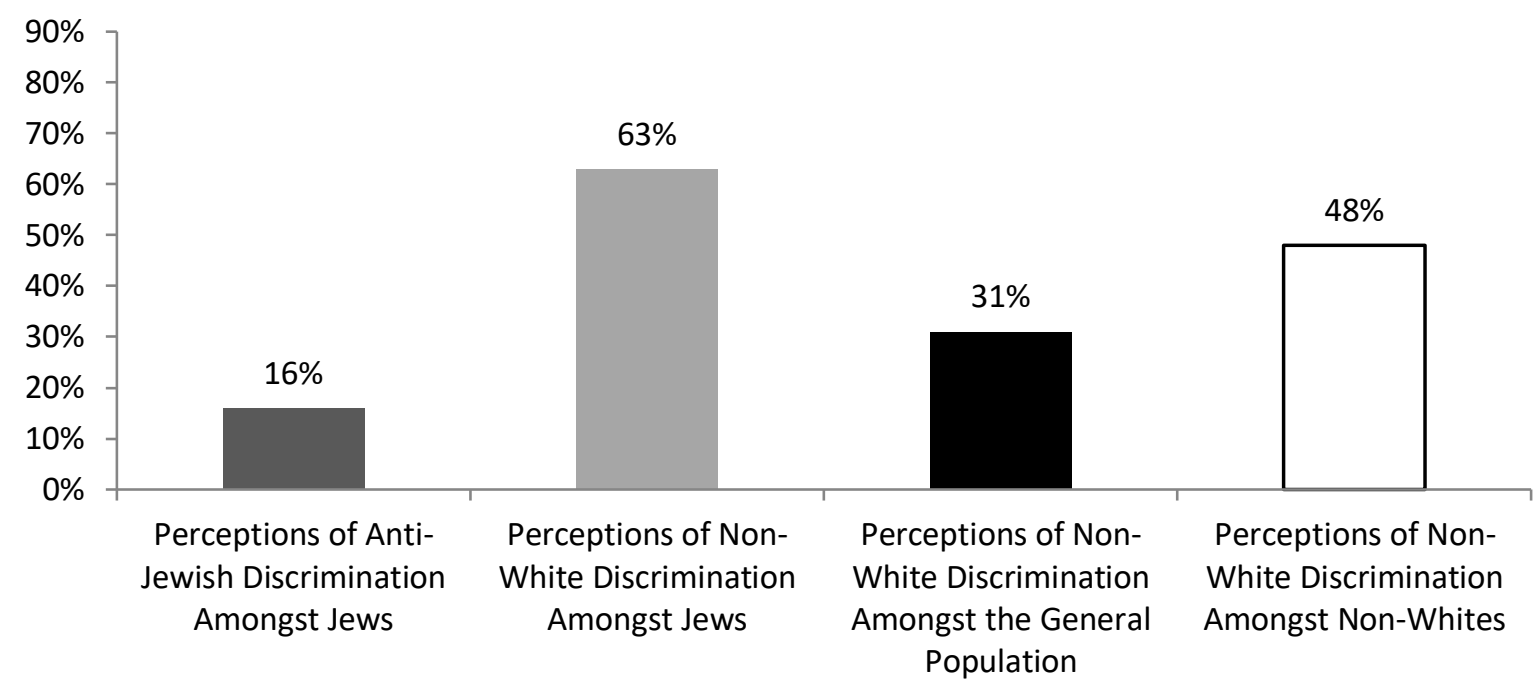

Note: Jewish Sample $n=512$, Non-White Sample $n=2,657$ General Population $n=3,328$

Percentages represent all 'strongly agree' and 'slightly agree'

Although Jewish voters do not perceive antisemitism as a widespread problem, this is not due to a more general dismissal of prejudice as a social issue. In fact, Jews were more likely to see discrimination as a significant problem for other ethnic minorities than the white majority or even ethnic minority voters themselves. There is a puzzle here in that such an attitude towards racial prejudice is typically associated with higher levels of support for Labour as the party with the strongest record of opposing racial discrimination. Jewish voters are thus unusual in demonstrating intense concern with racial discrimination, but nonetheless rejecting the Labour party at higher rates than the general population.

Finally, we hypothesised that the leadership of Jeremy Corbyn may be especially off-putting for Jewish voters. Figure 3 begins to address this claim by comparing approval of the party leaders among Jewish voters and the general population. The scale of the rejection of the Labour leader is noteworthy; $80 \%$ score Jeremy Corbyn negatively, suggesting that he represents a significant barrier to Labour support. Only 10\% have a positive impression of him, well below the $44 \%$ share of the general public who said they liked the Labour leader. The difference between British Jews and the general population on ratings of Corbyn is even greater than that found in propensity to ever vote Labour. Conversely, Theresa May's results are much less polarised amongst Jewish voters, though they are more likely to perceive her more favourably than the wider electorate. 


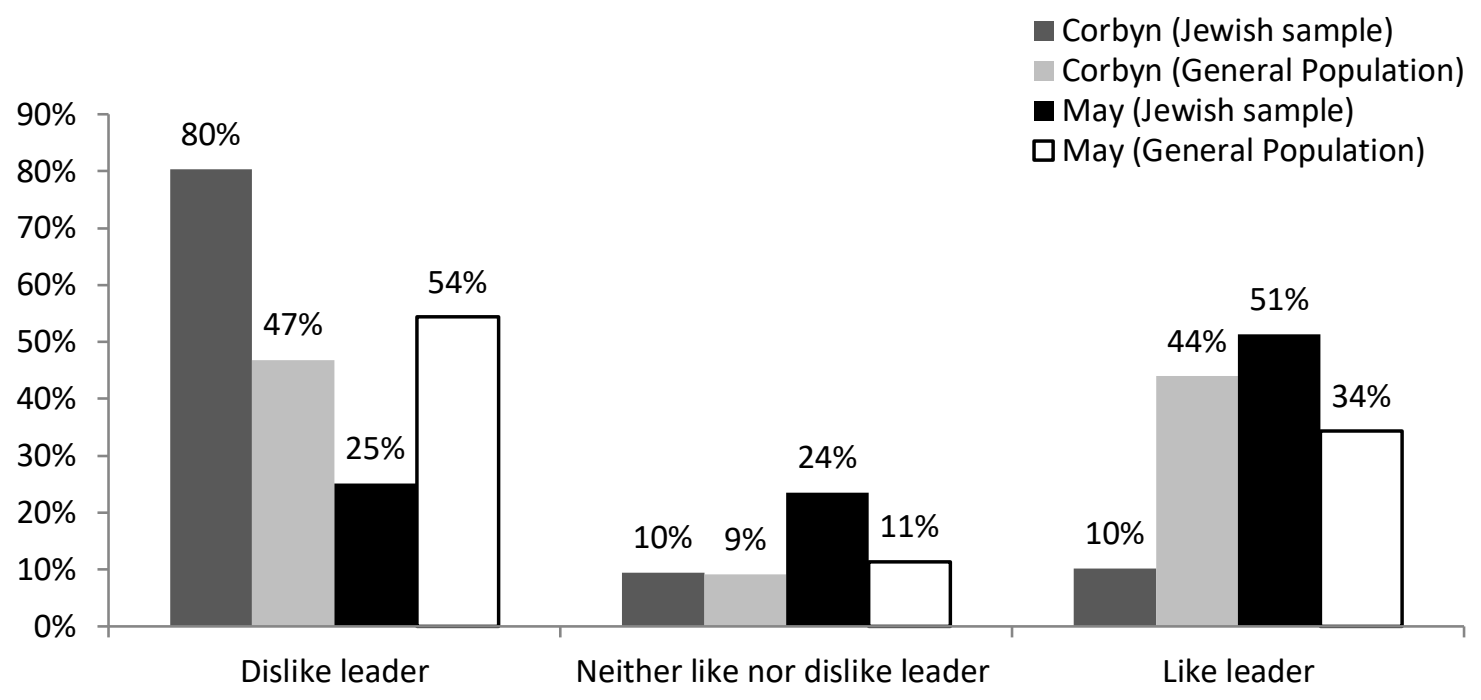

Note: Jewish Sample $n=512$, General Population $n=31,196$

Original 0-10 scale has been recoded into three categories; 0-4 = 'Dislike leader', 5 = 'Neither like nor dislike leader', 6-10 $=$ 'Like leader'

0-10 Mean scores for Corbyn Approval = 1.88 (Jewish Sample) \& 4.57 (General Population). 0-10 Means score for May Approval = 5.44 (Jewish Sample) \& 3.85 (General Population)

These results show a relationship with parties which is unrecognisable from the historic accounts which depict Jews as evenly divided in their vote choice as recently as 2010, suggesting Jewish voters have become more negative about Labour under Corbyn's leadership. The small sample of Jewish respondents from the British Election Study online panel also show a greater divergence from the wider population after Corbyn is elected leader in 2015; average Labour vote intention is some 10 points lower post-Corbyn's election (with no change with the wider population) and mean approval of the Labour leader is almost 2 points lower on a 10 point scale amongst Jewish respondents than the general population after Corbyn's election, with no significant difference between the two groups prior to $2015 .^{7}$

\section{Multivariate Analysis}

Tables 2 and 3 show results of multivariate OLS regressions of propensity to vote for the Conservatives and Labour respectively. The first model includes all demographic predictors; the

\footnotetext{
${ }^{7}$ A full breakdown of the results can be found in the appendix
} 
second model adds sociotropic perceptions of discrimination (against both Jews and non-whites) and the final model adds assessments of both main party leaders.

Looking first at Conservative support, structural factors do not play much role in explaining the Conservative lean of our Jewish sample. There is no significant age effect, despite the strong age gradient in party support within the broader electorate (Harrison 2018, Prosser et al 2017). We also observe no effect for gender or for residence in Greater London. We do see that, in line with the general population (Surridge 2017), Jewish voters with a degree report lower propensity to vote Conservative, as do those who self-define as working class. Demographic profile is more helpful in explaining propensity to vote Labour. Younger and female respondents are more inclined to support Labour, as are those with degrees and those who self-define as working class. The demographic predictors of Jewish propensity to support Labour are similar to those in the general population. However, the size of these effects is not sufficient to explain the aggregate Conservative advantage among Jewish voters, which we find among all demographic groups in our sample. Demographic factors, in short, do not fully explain the distinctive pattern of party support among Jewish voters.

The second model tests whether this distinctive pattern of support may instead be driven by sociotropic perceptions of prejudice (Heath et al 2013), both against minorities generally and Jews specifically. The results here are counter to hypothesis H2ii; that Conservative support is a product of perceptions of linked fate. Specifically, whilst we observe significant relationships with perceptions of general racial prejudice and both supporting Labour and rejecting the Conservatives, we don't observe any significant effect of perceptions of anti-Jewish discrimination on support for either party. In addition, we should recall that few Jewish respondents saw antisemitism as a significant barrier to progressing in society. This may be due to the question wording, as the specific manifestations of prejudice faced by Britain's Jews may not necessarily imitate those of other ethnic minority groups. By referring to being 'held back in society', our measure implies a relative group economic or social status disadvantage, for example due to "ethnic penalties" in the work force (Heath \& McMahon 1997). Should antisemitism manifest itself primarily in different ways, such as physical violence or threats to religious or cultural expression, then perhaps our measure may not effectively capture distinctive Jewish concerns about antisemitism, which are less to do with socio-economic disadvantage. However, notwithstanding this possibility, we do not find evidence of Jewish voters mobilising politically in response to perceptions of discrimination against their own group as other British ethnic minorities do (Sanders et al 2014, Saggar 2000). 
This null finding of the influence of societal antisemitism is accentuated by the highly significant effects that we find for perceptions of general racial prejudice. Jewish voters who see discrimination against other ethnic minorities as a significant problem expressed higher Labour support and greater rejection of the Conservatives (as do British racial minorities generally, see Sanders et al 2014, Heath et al 2013). The effect of having a degree loses its significance once this more general perceptions of prejudice measure is introduced, suggesting the more liberal views of graduates on racial equality (Sears 1969, Schuman et al 1997, Sniderman \& Piazza 1993) may be one reason for this education difference in party support (Surridge 2017). However, this only intensifies the puzzle of Jewish political leanings: British Jews are far more likely to believe than voters in general to believe that prejudice is a significant problem, this perception predicts support for Labour within the Jewish sample, yet overall support for Labour among Jewish voters is very low, despite their greater concern with prejudice. 
Table 2 - OLS Regression of propensity to vote Conservative

\begin{tabular}{|c|c|c|c|}
\hline $\begin{array}{l}\text { Propensity to } \\
\text { Vote Con }\end{array}$ & Model 1 & Model 2 & Model 3 \\
\hline Age & $\begin{array}{l}-0.09 \\
(0.13)\end{array}$ & $\begin{array}{l}0.06 \\
(0.13)\end{array}$ & $\begin{array}{l}-0.18 \\
(0.10)\end{array}$ \\
\hline Gender & $\begin{array}{l}-0.31 \\
(0.45)\end{array}$ & $\begin{array}{l}-0.40 \\
(0.44)\end{array}$ & $\begin{array}{l}-0.82 * \\
(0.33)\end{array}$ \\
\hline London & $\begin{array}{l}0.30 \\
(0.47)\end{array}$ & $\begin{array}{l}0.50 \\
(0.47)\end{array}$ & $\begin{array}{l}0.39 \\
(0.35)\end{array}$ \\
\hline Degree & $\begin{array}{l}-1.16 * \\
(0.45)\end{array}$ & $\begin{array}{l}-0.84 \\
(0.46)\end{array}$ & $\begin{array}{l}-0.39 \\
(0.34)\end{array}$ \\
\hline Social Class & $\begin{array}{l}2.10 * \\
(0.68)\end{array}$ & $\begin{array}{l}2.42^{* * *} \\
(0.66)\end{array}$ & $\begin{array}{l}1.00 \\
(0.52)\end{array}$ \\
\hline Non-White Disc. & & $\begin{array}{l}-0.72 * * * \\
(0.18)\end{array}$ & $\begin{array}{l}-0.20 \\
(0.14)\end{array}$ \\
\hline Anti-Jewish Disc. & & $\begin{array}{l}-0.00 \\
(0.19)\end{array}$ & $\begin{array}{l}-0.16 \\
(0.14)\end{array}$ \\
\hline Like Corbyn & & & $\begin{array}{l}-0.46 * * * \\
(0.07)\end{array}$ \\
\hline Like May & & & $\begin{array}{l}0.71 * * * \\
(0.07)\end{array}$ \\
\hline Constant & 5.00 & 6.66 & 5.48 \\
\hline R2 & 0.05 & 0.11 & 0.52 \\
\hline
\end{tabular}

Note: ${ }^{*}=$ significance at $\mathrm{p}=0.05,{ }^{* *}=$ significance at $\mathrm{p}=0.01, * * *=$ significance at $\mathrm{p}=0.00 . \mathrm{N}=512$ 
Table 3 - OLS Regression of propensity to vote Labour

\begin{tabular}{|c|c|c|c|}
\hline $\begin{array}{l}\text { Propensity to } \\
\text { Vote Labour }\end{array}$ & Model 1 & Model 2 & Model 3 \\
\hline Age & $\begin{array}{l}-0.36^{*} \\
(0.12)\end{array}$ & $\begin{array}{l}-0.47^{* * *} \\
(0.12)\end{array}$ & $\begin{array}{l}-0.22^{*} \\
(0.10)\end{array}$ \\
\hline Gender & $\begin{array}{l}1.02 * \\
(0.42)\end{array}$ & $\begin{array}{l}1.17^{*} \\
(0.42)\end{array}$ & $\begin{array}{l}1.39 * * * \\
(0.33)\end{array}$ \\
\hline London & $\begin{array}{l}-0.64 \\
(0.45)\end{array}$ & $\begin{array}{l}-0.91^{*} \\
(0.45)\end{array}$ & $\begin{array}{l}-0.64 \\
(0.35)\end{array}$ \\
\hline Degree & $\begin{array}{l}1.37^{*} \\
(0.43)\end{array}$ & $\begin{array}{l}1.03^{*} \\
(0.43)\end{array}$ & $\begin{array}{l}0.65 \\
(0.34)\end{array}$ \\
\hline Social Class & $\begin{array}{l}-1.93^{*} \\
(0.64)\end{array}$ & $\begin{array}{l}-2.01 * * \\
(0.64)\end{array}$ & $\begin{array}{l}-0.74 \\
(0.49)\end{array}$ \\
\hline Non-White Disc. & & $\begin{array}{l}0.79 * * * \\
(0.17)\end{array}$ & $\begin{array}{l}0.19 \\
(0.14)\end{array}$ \\
\hline Anti-Jewish Disc. & & $\begin{array}{l}-0.13 \\
(0.18)\end{array}$ & $\begin{array}{l}0.03 \\
(0.14)\end{array}$ \\
\hline Like Corbyn & & & $\begin{array}{l}0.64 * * * \\
(0.07)\end{array}$ \\
\hline Like May & & & $\begin{array}{l}-0.42^{* * *} \\
(0.07)\end{array}$ \\
\hline Constant & 7.42 & 5.61 & 4.90 \\
\hline R2 & 0.10 & 0.18 & 0.51 \\
\hline
\end{tabular}

Our final hypothesis proposes that Jeremy Corbyn's leadership of the Labour party may play a significant role in explaining this pattern of Jewish party support. Our third model tests the effect of both party leaders' approval ratings. We find highly significant results for both. However, it is difficult from these results to infer a specifically anti-Corbyn effect with confidence for two reasons. Firstly, there is an endogeneity problem with these two measures - it is impossible with cross-sectional data to know for certain whether views of a leader influence views of a party, or vice versa. Secondly, strong leadership coefficients are on their own not sufficient evidence to conclude that there is a distinctive "Jeremy Corbyn effect" amongst Jewish voters, as it remains possible that views of Corbyn have a similar effect on non-Jewish voters. 
To address these problems as best as we can using cross-sectional individual level data, we show two things; firstly the marginal effects predictions of assessments of Jeremy Corbyn by propensity to vote Labour (Figure 4), and secondly the marginal effects predictions of propensity to vote Conservative by assessments of Theresa May (Figure 5). To increase statistical power, we recoded the original 11 point scales of the independent variables into 5 point scales, with responses 1-4 and 6-9 been pooled together, with responses 0, 5 and 10 remaining the same.

As we might expect, views of Corbyn become more positive for respondents who are more likely to support Labour. However the incline is flatter for our Jewish sample; Jewish voters give significantly lower ratings of Jeremy Corbyn at every level of propensity to support Labour. These results suggest that Corbyn is disliked beyond what would be expected purely through negative perceptions of the Labour party. Equally, Figure 5 shows that Jews with a negative or neutral opinion of Theresa May are significantly more likely to support the Conservatives than non-Jews. Even if the relationship between leadership evaluations and propensity to vote was the same between Jews and non-Jews, that the overall assessments of Corbyn are so low amongst Jews would imply very low levels of support for Labour. However, the fact that our analysis shows that this relationship is not the same for Jews, whilst not fully accounting for endogeneity, does provide two significant findings; firstly that there is something which leads Jews who hold negative evaluations of the Conservative leader to still be more likely than non-Jews to vote for the Tories regardless, and secondly that Jews of all levels of attachment to Labour are more likely to hold Corbyn in poor esteem. ${ }^{8}$

\footnotetext{
${ }^{8}$ Marginal effects predictions of approval of Theresa May by propensity to vote Conservative, as well as the marginal effects of assessments of Corbyn on propensity to vote Labour, are found in the appendix
} 
Figure 4-Marginal effects predictions of Corbyn approval by propensity to vote Labour

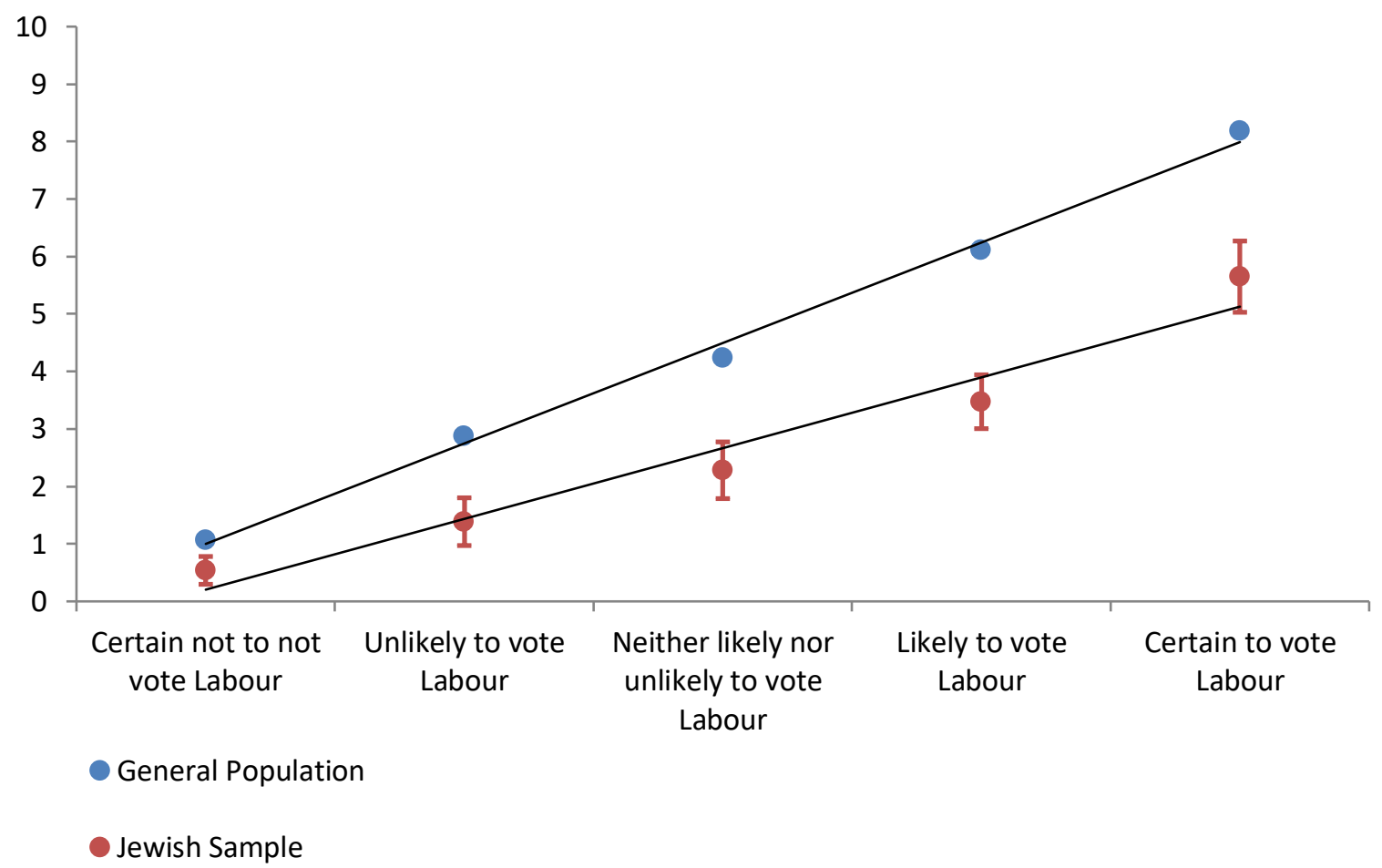

Note: Jewish Sample $n=512$, General Population $n=31,196$

Propensity to vote has been recoded into five categories; 0 = 'Certain note to vote', 1-4 = 'Unlikely to vote', 5 = 'Neither likely nor unlikely to vote', $6-9$ = 'Likely to vote', 10 = 'Certain to vote'

Error bars show parameters of $95 \%$ confidence intervals 
Figure 5 - Marginal effects predictions of propensity to vote Conservative by approval of May

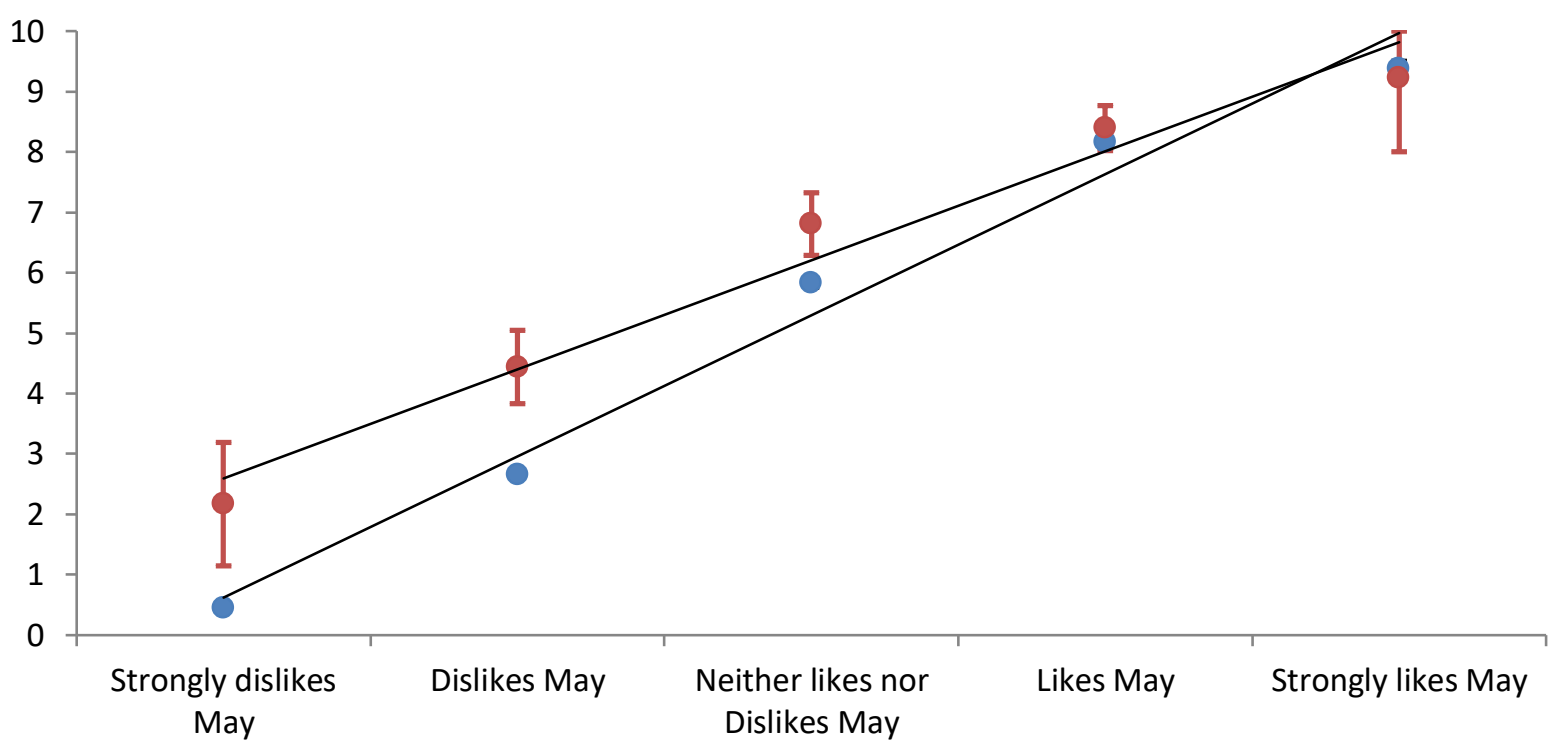

General Population

- Jewish Sample

Note: Jewish Sample $n=512$, General Population $n=31,196$

Leadership assessments have been recoded into five categories; 0 = 'Strongly dislike', 1-4 = 'Dislike', 5 = 'Neither like nor dislike', 6-9 = 'Like', 10 = 'Strongly like'

\section{Error bars show parameters of $95 \%$ confidence intervals}

\section{Another test of the Corbyn effect: aggregate vote change patterns in local and general elections}

It is difficult to demonstrate a specific "Corbyn effect" on Jewish political preferences as we do not have comparable data on Jewish preferences before and after Jeremy Corbyn became Labour leader. However, we can test for a "before and after" effect in aggregate election results data, looking at vote shifts before and after Corbyn's election as leader in areas with large Jewish communities, compared to overall patterns of vote shift. If Jewish voters' Conservative leanings reflect a reaction to Jeremy Corbyn specifically, there should be distinctive swings away from Labour and towards the Conservatives in areas with large Jewish electorates when we compare elections conducted immediately before and immediately after his rise to the leadership. We 
focus on the small subset of wards and constituencies with substantial Jewish populations (above one per cent of the total resident population in the 2011 Census), and examine whether there is a correlation between the size of the local Jewish population and the performance of Labour and the Conservatives. If Jeremy Corbyn's election as Labour leader prompted a substantial shift of Jewish voters away from Labour and towards the Conservatives, then the larger the local Jewish population, the worse Labour's performance should be, and the better the Conservatives' performance should be.

Table 4 below looks at the results of a series of regression models testing the link between local Jewish population share and party performance, in the subset of wards or constituencies where the local Jewish population is $1 \%$ or higher. The first row shows the results from a simple model with just proportion of Jewish population, then the subsequent rows test the robustness of this correlation to the introduction of various controls. When we look at Labour performance, on the left hand side of the table, we find a robust negative correlation between Jewish population and Labour vote change in each of the three election cycles. This correlation is highly significant and robust to the introduction of controls, and is not driven by outliers. ${ }^{9}$ Labour candidates standing in areas with substantial Jewish communities did substantially worse in elections held since Corbyn became leader than they did in the same places in elections held under Ed Miliband's leadership. When we look at Conservative performance, there is a similarly sized positive correlation in local elections, though not in the general elections data. It is not clear what explains the difference, though one possibility may be that most of the constituencies with large Jewish communities are in London and other large, diverse metropolitan areas, where the Conservatives under-performed more generally in 2017.

We must always be cautious about inferences from aggregate data. For instance, whilst Labour's underperformance may be a consequence of Jewish voters penalising them at the ballot box, it might alternatively be non-Jews in areas with high Jewish populations swinging away from Labour and towards the Conservatives. This possibility could either be non-Jews opting for the Conservatives in response to an increasing number of Jewish neighbours who have historically been associated with the Labour party, or indeed in solidarity with Jewish voters resulting from Labour's antisemitism crisis. We think that the first possibility is unlikely, firstly because the growth of Jewish population is unlikely to have been significant in the relatively short time frames between these elections and secondly because given Labour's recent record on

\footnotetext{
${ }^{9}$ Scatter plots of the results are presented in the Appendix - the negative correlation is clearly visible on these, and is not driven by outlier results
} 
antisemitism it is as likely that antisemitic voters would flock to Labour, not the Conservatives. The second possibility- that of solidarity- is slightly more likely, although it would be strange if non-Jews reacted more strongly than Jews to antisemitism. Notwithstanding these possibilities, the pattern of the effects here is consistent with our individual level evidence suggesting a distinctive negative Corbyn effect on Jewish voters' support for Labour since 2015. As such, although all of our sources have limitations, they do all point in the same direction, suggesting a shift of Jewish voters away from Labour and towards the Conservatives in the period since Jeremy Corbyn's election as Labour party leader in 2015.

While we cannot know what individual level changes have driven these aggregate relationships, the overall pattern is consistent with our individual level evidence, suggesting a distinctive negative Corbyn effect on Jewish voters' support for Labour since 2015. As such, although all of our sources have limitations, they do all point in the same direction, suggesting a shift of Jewish voters away from Labour and towards the Conservatives in the period since Jeremy Corbyn's election as Labour party leader in 2015.

Table 4 - Regression models of Labour and Conservative performance and share of Jewish residents in the ward/constituency in 2012-16, 2014-2018 local elections and between the 2015-2017 general elections

\begin{tabular}{|c|c|c|c|c|c|c|c|}
\hline & & $\begin{array}{l}\text { Model 1: } \\
\text { Jewish } \\
\text { share of } \\
\text { residents } \\
\text { only }\end{array}$ & $\begin{array}{l}\text { Model 2: } \\
\text { Controls for } \\
\text { education }\end{array}$ & $\begin{array}{l}\text { Model 3: } \\
\text { Controls for } \\
\text { economic } \\
\text { deprivation }\end{array}$ & $\begin{array}{l}\text { Model 4: } \\
\text { Controls for } \\
\text { age }\end{array}$ & $\begin{array}{l}\text { Model 5: } \\
\text { Controls for } \\
\text { education, } \\
\text { class and } \\
\text { age }\end{array}$ & $\begin{array}{c}N \\
(\max / \min )\end{array}$ \\
\hline \multirow[t]{3}{*}{$\begin{array}{l}\text { Labour Vote } \\
\text { Change }\end{array}$} & $\begin{array}{l}\text { 2012-16 } \\
\text { local } \\
\text { elections }\end{array}$ & $\begin{array}{c}-0.61 * \\
(0.17)\end{array}$ & $\begin{array}{l}-0.46^{*} \\
(0.17)\end{array}$ & $\begin{array}{l}-0.46^{*} \\
(0.17)\end{array}$ & $\begin{array}{l}-0.51 * \\
(0.18)\end{array}$ & $\begin{array}{l}-0.49 * \\
(0.18)\end{array}$ & $27 / 27$ \\
\hline & $\begin{array}{l}2015-17 \\
\text { general } \\
\text { election }\end{array}$ & $\begin{array}{l}-0.38^{*} \\
(0.15)\end{array}$ & $\begin{array}{l}-0.38^{*} \\
(0.15)\end{array}$ & $\begin{array}{l}-0.37^{*} \\
(0.15)\end{array}$ & $\begin{array}{l}-0.40 * \\
(0.15)\end{array}$ & $\begin{array}{l}-0.38 * \\
(0.16)\end{array}$ & $34 / 34$ \\
\hline & $\begin{array}{l}\text { 2014-18 } \\
\text { local } \\
\text { elections }\end{array}$ & $\begin{array}{r}-0.29 * \\
(0.08)\end{array}$ & $\begin{array}{l}-0.30 * \\
(0.08)\end{array}$ & $\begin{array}{l}-0.25 * \\
(0.07)\end{array}$ & $\begin{array}{l}-0.27 * \\
(0.07)\end{array}$ & $\begin{array}{l}-0.24 * \\
(0.07)\end{array}$ & $106 / 94$ \\
\hline \multirow[t]{3}{*}{$\begin{array}{l}\text { Conservative } \\
\text { Vote } \\
\text { Change }\end{array}$} & $\begin{array}{l}2012-16 \\
\text { local } \\
\text { elections }\end{array}$ & $\begin{array}{l}0.67 * \\
(0.16)\end{array}$ & $\begin{array}{c}0.62 * * \\
(0.17)\end{array}$ & $\begin{array}{l}0.65 * \\
(0.18)\end{array}$ & $\begin{array}{l}0.65 * \\
(0.17)\end{array}$ & $\begin{array}{l}0.65 * \\
(0.17)\end{array}$ & $28 / 28$ \\
\hline & $\begin{array}{l}2015-17 \\
\text { general } \\
\text { election }\end{array}$ & $\begin{array}{c}0.08 \\
(0.19)\end{array}$ & $\begin{array}{c}0.06 \\
(0.13)\end{array}$ & $\begin{array}{c}0.11 \\
(0.15)\end{array}$ & $\begin{array}{c}0.13 \\
(0.18)\end{array}$ & $\begin{array}{l}0.07 \\
(0.13)\end{array}$ & $34 / 34$ \\
\hline & $\begin{array}{l}2014-18 \\
\text { local } \\
\text { elections }\end{array}$ & $\begin{array}{l}0.33 * \\
(0.08)\end{array}$ & $\begin{array}{l}0.29 * \\
(0.07)\end{array}$ & $\begin{array}{l}0.31 * \\
(0.08)\end{array}$ & $\begin{array}{l}0.32 * \\
(0.08)\end{array}$ & $\begin{array}{l}0.32 * \\
(0.06)\end{array}$ & $106 / 94$ \\
\hline
\end{tabular}




\section{Discussion}

This paper had two principle aims. Firstly, we sought to offer more robust evidence on the patterns of party support among British Jews than has hitherto been available. Secondly, we attempted to explain these patterns, firstly using socio-economic explanations, then by questioning whether sociotropic perceptions of prejudice influence the political choices of Jewish voters, and finally if the post-2015 leadership of the Labour party can account for the Conservative leanings of Anglo-Jewry. Since no single data source could fully answer these questions, we used multiple individual and aggregate level datasets to triangulate our results. Our study represents the most detailed and reliable evidence on voting behavior of British Jews available to date.

Our study shows a rather bleak outlook for the Labour Party. The difference in levels of Jewish support for the main two parties is dramatic, and moreover, cannot be explained by the composition of the Jewish electorate. The current levels of rejection of Labour are remarkable for a group once strongly associated with the British left, and one with a recent history of diverse party support. There is some silver lining for Labour in that that Jewish respondents in demographic segments typically associated with Labour support are more inclined to consider supporting the party at future elections. However, the propensity to support the Conservatives is high across all demographic groups, and it is this point which is worthier of comment: if Jews of all social backgrounds now see the Conservatives as the party of choice, what has led to this outcome?

We tested the hypothesis that perceptions of linked fate may account for Jewish distinctiveness and show that the politics of prejudice and discrimination among British Jews works differently than among Britain's larger and more extensively researched non-white minority groups. Antisemitism is not seen as a significant barrier to advancement by the majority of Anglo-Jewry, and plays no significant role in predicting their wider political attitudes, including support for the Conservatives. Future research may show that alternative measures of linked fate, reflecting other manifestations of anti-Jewish prejudice may prove to be influential in driving political attitudes, but given the measure we have used has been so robust for other racial minority groups in a variety of settings, we can still conclude that Jewish voters' perceptions of and political reactions to discrimination are different to those of other ethnic minorities.

However, whilst sociotropic perceptions of anti-Jewish prejudice are negligible, racial prejudice more generally is viewed by Jews as a much more significant social problem than it is amongst the general population. As with other ethnic minorities, concern about racial prejudice also 
predicts greater support for Labour among Jewish respondents. The fact that Jewish voters believe that prejudice is a significant social problem holding back ethnic minorities, and yet they still display such strong preferences for the Conservatives shows two things. Firstly, that we must theorise the political attitudes of British Jews as not only distinctive to those of the general population but also from other minorities. Secondly, that the pull towards the Conservatives (or push away from Labour) is of sufficient magnitude that it trumps widely shared concerns about prejudice, which are usually associated with voting for Labour.

We also hypothesized that the perceptions of the post-2015 Labour party, personified by Jeremy Corbyn, may be a factor in this alignment of Jewish voters with the Conservatives. The multiple pieces of evidence we have presented, while incomplete on their own, all add up to a picture consistent with this hypothesis. Jewish voters' evaluations of Corbyn are very negative, much more so than those of the general population, and we show in our marginal effects plots that Corbyn's underperformance amongst Jews holds even for those likely or even certain to vote Labour, thereby suggesting that levels of disapproval are not simply a product of partisanship. On the other side of the ledger, Jews who hold negative views of the Conservative leader nevertheless remain more likely to support the Conservatives than non-Jews with similar perceptions of May, showing that there is still something making Jews more inclined to vote Conservative than non-Jews even allowing for this factor. Although we cannot fully address the issue of endogeneity with our data, our analysis of aggregate vote change adds to this a temporal dimension and suggests a strong negative correlation between the size of the local Jewish population and Labour's performance in elections since Corbyn became Labour leader.

It is not our intention to be overly reductivist with this point. The antisemitism crisis which has engulfed Labour has been found within all levels of the party, and its roots predate Corbyn's tenure as leader. Measuring a comprehensive range of attitudes towards the Labour brand generally, and how the post-2015 crisis has shaped them, is beyond the scope of this paper as we lack sufficient data. However, impressions of Corbyn are an important element in this broader crisis, as he has been accused of not doing enough to condemn antisemitism in his party, and as such the negative effect of Corbyn's leadership in our data tells us something meaningful about how the current leadership is acting as a significant barrier for Jewish voters. 


\section{Bibliography}

Abramson, Sarah, Graham, David \& Boyd, Johnathan (2011) "Key trends in the British Jewish community: A review of data on poverty, the elderly and children" Institute for Jewish Policy Research https://www.jpr.org.uk/documents/Key $\% 20$ trends $\% 20$ in $\% 20$ the $\% 20$ British $\% 20 J$ ewish $\% 20$ co mmunity.pdf

Alderman, Geoffrey (1975) “The Politics of Race: Not Quite British: The Political Attitudes of Anglo-Jewry" in Ivor Crewe (ed) Politics of Race London: Croom Helm

Alderman, Geoffrey (1983) The Jewish Community in British Politics London: Clarendon Press

Alderman, Geoffrey (1992) Modern British Jewry London: Clarendon Press

Alderman, Geoffrey (2011) "Jews and Electoral Politics in the United Kingdom: A Contemporary Note" Jewish Journal of Sociology 52 (1) pp.69-74

Alderman, Geoffrey (2012) "London Jewry and the London Mayoral Election of 2012: A Note" Jewish Journal of Sociology 54 pp.57-63

Bolton, Matt \& Pitts, Frederick Harry (2018) Corbynism: A Critical Approach Bingley: Emerald Boyd, Jonathan (2015) “Where Jewish Votes Matter Most" Institute for Jewish Policy Research http://www.jpr.org.uk/documents/JPR.Where Jewish votes may matter most.Guide to 201

\section{General Election.pdf}

Clements, Ben \& Spencer, Nick (2014) "Voting and Values in Britain: Does Religion Count?" Theos Report https://www.theosthinktank.co.uk/cmsfiles/archive/files/Reports/Voting $\% 20$ and $\% 20$ Values $\%$ 20in\%20Britain $\% 2012$.pdf

Dancygier, Rafaela \& Saunders, Elizabeth (2006) “A New Electorate? Comparing Preferences and Partisanship between Immigrants and Natives" American Journal of American Science 50(4) pp.962-981

Dawson, Michael (1994) Behind the Mule: Race and Class in African-American Politics Princeton NJ: Princeton University Press.

Evans, Geoffrey \& Mellon, Jon (2016) 'Working Class Votes and Conservative Losses: Solving the UKIP Puzzle" Parliamentary Affairs 69 pp.464-479

Edward Fieldhouse et al (2018) "British Election Study Online Panel” pp.1-14 
Fine, Robert \& Spencer, Philip (2017) Antisemitism and the Left: On the Return of the Jewish Question Manchester: Manchester University Press

Graham, David \& Boyd, Johnathan (2010) "Committed, Concerned and Conciliatory: The Attitudes of Jews in Britain towards Israel" Institute for Jewish Policy Research http://www.jpr.org.uk/documents/Committed, $\% 20$ concerned $\% 20$ and $\% 20$ conciliatory: $\% 20$ The $\% 20$ attitudes $\% 20$ of $\% 20$ Jews $\% 20$ in $\% 20$ Britain $\% 20$ towards $\% 20$ Israel.pdf

Graham, David (2013) “2011 Census Results (England and Wales) A Tale of Two Jewish Populations" Institute for Jewish Policy Research http://www.jpr.org.uk/documents/2011\%20Census $\% 20$ results $\% 20$ \%20A\%20Tale $\% 20$ of $\% 20$ Two $\% 20$ Jewish $\% 20$ Populations.pdf

Graham, David; Schmool, Marleena \& Waterman, Stanley (2007) “Jews in Britain, a Snapshot from the 2001 Census" Institute for Jewish Policy Research http://www.jpr.org.uk/documents/Jews $\% 20 \mathrm{in} \% 20$ Britain: $\% 20 \mathrm{~A} \% 20$ snapshot $\% 20$ from $\% 20$ the \%202001\%20Census.pdf

The Guardian (2016) "Labour opens inquiry into antisemitism allegations at Oxford student club" The Guardian February $17^{\text {th }}$ https://www.theguardian.com/politics/2016/feb/17/labourcondemns-antisemitism-oxford-university-labour-club-claims

The Guardian (2016) "Naz Shah: timeline of events leading to MP's suspension from Labour" The Guardian April 27 $7^{\text {th }}$ https://www.theguardian.com/politics/2016/apr/27/naz-shah-timelineof-events-leading-to-mps-suspension-from-labour

The Guardian (2019) 'Labour investigates Liverpool members over 'bullying' of Luciana Berger” The Guardian February 10 $10^{\text {th }}$ https://www.theguardian.com/politics/2019/feb/10/labourinvestigates-liverpool-branch-over-bullying-of-luciana-berger-wavertree

The Guardian (2019) "Labour MP Ian Austin quits the party over 'culture of antisemitism”" The Guardian February 22 $2^{\text {nd }}$ https://www.theguardian.com/politics/2019/feb/22/labour-mp-ianaustin-quits-the-party 
Harrison, Sarah (2018) "Young Voters" in Tongue, Jonathan, Leston-Bandeira, Cristina \& Stuart Wilks-Heeg (eds) Britain Votes 2017 Oxford: Oxford University Press

Heath, Anthony, Jowell, Roger, Curtice, John, Evans, Geoff, Field, Julia \& Witherspoon, Sharon (1991) Understanding Political Change: The British Voter 1964-1987, Oxford: Pergamon

Heath, Anthony \& McMahon, Doreen (1997) "Education and Occupational Attainment: The Impact of Ethnic Origins" in Valerie Karn (ed) Education, Employment and Housing among Ethnic Minorities in Britain London: HMSO pp. 91-113

Heath, Anthony; Fisher, Stephen; Sanders, David \& Sobolewska, Maria (2011) "Ethnic Heterogeneity in the Social Bases of Voting at the 2010 British General Election" Journal of Elections, Public Opinion and Parties 21(2) pp.255-277

Heath, Anthony; Fisher, Stephen; Sanders, David; Rosenblat, Gemma \& Sobolewska, Maria (2013) The Political Integration of Ethnic Minorities Oxford: OUP

Hirsh, David (2016) “The Chakrabarti report failed, again and again” The Jewish Chronicle, July 6 ${ }^{\text {th }}$ 2016 https://www.thejc.com/comment/comment/the-chakrabarti-report-failed-again-andagain-1.60223

Hirsh, David (2017) Contemporary Left Antisemitism London: Routledge

House of Commons Report (2016) “Government Response to Home Affairs Committee Report: "Anti-Semitism in the UK"' https://www.parliament.uk/documents/commonscommittees/home-affairs/CM9386-Select-Comittee-Response-Antisemitism-in-UK.pdf

Hwang, Sean-Shong, Fitzpatrick, Kevin \& Helms, David (1998) "Class Differences in Racial Attitudes: A Divided Black America?” Sociological Perspectives 41(2) pp.367-380

Institute for Jewish Policy Research (2010) “The Political Leanings of British Jews” Institute for Jewish Policy Research http://www.jpr.org.uk/documents/The $\% 20$ political $\% 20$ leanings $\% 20$ of $\% 20$ British $\% 20$ Jews.pdf 
Jewish Chronicle (2015) "Huge majority of UK Jews will vote Tory" Jewish Chronicle April $7^{\text {th }}$ http://www.thejc.com/news/uk-news/133505/huge-majority-british-jews-will-vote-tory-jc-poll$\underline{\text { reveals }}$

Jewish Chronicle (2016) "Labour support amongst British Jews collapses to 8.5 percent" Jewish Chronicle May $4^{\text {th }}$ https://www.thejc.com/news/uk-news/labour-support-among-british-jewscollapses-to-8-5-per-cent-1.56476

Jewish Chronicle (2017) "Labour support just to 13 percent amongst British Jews" Jewish Chronicle May $4^{\text {th }}$ https://www.thejc.com/news/uk-news/labour-support-among-british-jewscollapses-to-8-5-per-cent-1.56476

Keleman, Paul (2000) "Looking the Other Way: The British Labour Party, Zionism and the Palestinians" in Collette \& Bird (eds) Jews, Labour \& the Left, 1918-48 London: Routledge Kotler-Berkowitz, Lawrence (2000) "Ethnicity and Political Behaviour Among American Jews: Findings from the National Jewish Population Survey 2000-01" Contemporary Jewry pp.132-157 Kotler-Berkowitz, Lawrence (2001) "Ethnicity and British Politics: Cohesion, Division and British Jews" Political Studies 49 pp.648-669

Kotler-Berkowitz, Lawrence (2002) "Social Cleavages and Political Divisions: A Comparative Analysis of British, American and South African Jews in the 1990s" Journal of Modern Jewish Studies 1(2) pp.204-233

Laponce, Jean A. (1988) “Left or Centre? The Canadian Jewish Electorate, 1953-1983.” Canadian Journal of Political Science 4: 691-714.

Martin, Nicole (2019). Ethnic minority voters in the UK 2015 general election: a breakthrough for the Conservative party? Electoral Studies, 57, 174-185. 
Maxwell, Rahsaan (2012) Ethnic Minority Migrants in Britain and France: Integration Trade-Offs

Cambridge: Cambridge University Press

Medding, Peter (1977) “Towards a General Theory of Jewish Political Interests and Behaviour" Jewish Journal of Sociology (19) pp.115-44

Medved, Michael (2013) "Jews, Conservatives and Canada" Commentary https://www.commentarymagazine.com/articles/jews-conservatives-and-canada/

Miller, Stephen; Margaret Harris \& Colin Schindler (2015) “The Attitudes of British Jews towards Israel" Yachad http://yachad.org.uk/wp-content/uploads/2015/11/British-JewishAttitudes-Towards-Israel-Yachad-Ipsos-Mori-Nov-2015.pdf

The New Statesman (2016) “Jewish Labour MP Ruth Smeeth was reduced to tears at Labour's anti-Semitism inquiry press conference" The New Statesman $30^{\text {th }}$ June https://www.newstatesman.com/politics/staggers/2016/06/jewish-labour-mp-ruth-smeethwas-reduced-tears-labour-s-anti-semitism

Philpot, Robert (2017) Margaret Thatcher: The Honorary Jew London: Biteback

Prosser, Chris, Fieldhouse, Ed, Green, Jane, Mellon, John \& Evans, Geoff (2018) "Did young voters turn out in droves for Corbyn? The myth of the 2017 Youthquake election" LSE Blog http://blogs.lse.ac.uk/politicsandpolicy/the-myth-of-the-2017-youthquake-election/ accessed $22 / 05 / 2018$

Rich, Dave (2016) The Left's Jewish Problem: Jeremy Corbyn, Israel \& Anti-Semitism London: Biteback

Rich, Dave (2018) "Anti-Semitism in the Radical Left and the British Labour Party" Kantor Position Papers http://kantorcenter.tau.ac.il/sites/default/files/Dave\%20Rich\%20180128.pdf

Sanders, David, Heath, Anthony, Fisher, Stephen \& Sobolewska, Maria (2014) “The Calculous of Ethnic Minority Voting in Britain” Political Studies 62(2) pp.230-251

Saggar, Shamit (1992) Race and Politics in Britain London: Harvester Wheatsheaf 
Saggar, Shamit (2000) Electoral Politics and Ethnic Pluralism in Britain. Manchester: Manchester University Press

Saggar, Shamit (2004) Race and British Electoral Politics London: Routledge

Schnapper, Dominique, Bordes-Benayoun, Chantal \& Raphäl, Freddy (2010) Jewish Citizenship in France: The Temptation of Being among One's Own. New Brunswick: Transaction Publishers

Schuman, Howard, Steeh, Charlotte, Bobo, Lawrence \& Krysan, Maria (1997) Racial Attitudes in America, Trends \& Interpretations Cambridge: Harvard University Press

Sears, David (1969) "Political Behaviour” in G. Lindzey \& E. Aronson (eds) Handbook of Social Psychology Reading, Massachusetts: Addison-Wesley

Smith. Gregory \& Martinez, Jessica (2016) "How the faithful voted: A preliminary 2016 analysis," Pew Research Center, November 9, http://www.pewresearch.org/fact-tank/2016/11/09/how-thefaithful-voted-a-preliminary-2016-analysis/

Sniderman, Paul \& Piazza, Thomas (1993) The Scar of Race Cambridge: Harvard University Press Sniderman, Paul, Ford, Rob \& Sobolewska, Maria (2015) YouGov Survey: After Paris - The Surprising Resilience of British Attitudes

Spencer, Nick (2017) The Mighty and the Almighty: How Political Leaders Do God London: Biteback Sonenshein, Raphael \& Valentino, Nicholas (2000) "The distinctiveness of Jewish Voting: A Thing of the Past?” Urban Affairs Review 35 pp.358-389

Staetsky, Daniel \& Boyd, Jonathan (2015) "Strictly Orthodox rising: What the demography of British Jews tells us about the future of the Community" Institute for Jewish Policy Research https://www.jpr.org.uk/documents/JPR 2015.Strictly Orthodox rising. What the demography _of_British_Jews_tells_us_about the future_of the_community.pdf

Surridge, Paula (2017) "How the Labour vote reflects a values-based realignment of the British electorate" LSE British Politics and Policy Blog http://blogs.lse.ac.uk/politicsandpolicy/how-thelabour-vote-reflects-a-values-based-realignment-among-the-british-electorate/ 
The Times of Israel (2016) 'UK Jews fume as lawyer in 'whitewash' anti-Semitism report gets top Labour job" The Times of Israel October $7^{\text {th }}$ https://www.timesofisrael.com/uk-jews-fume-aslawyer-in-whitewash-anti-semitism-report-gets-top-labour-job/

Tilley, James (2015) “We Don’t Do God? Religion \& Party Choice in Britain” British Journal of Political Science 45(4) pp.907-927

Wald, Kenneth (2016) “The Choosing People: Interpreting the Puzzling Politics of American Jewry" Politics and Religion 8 pp.4-35

\section{Appendix}

\section{Descriptive Results (Jewish Sample)}

Propensity to vote for [Party] (Jewish Sample, $n=512$ )
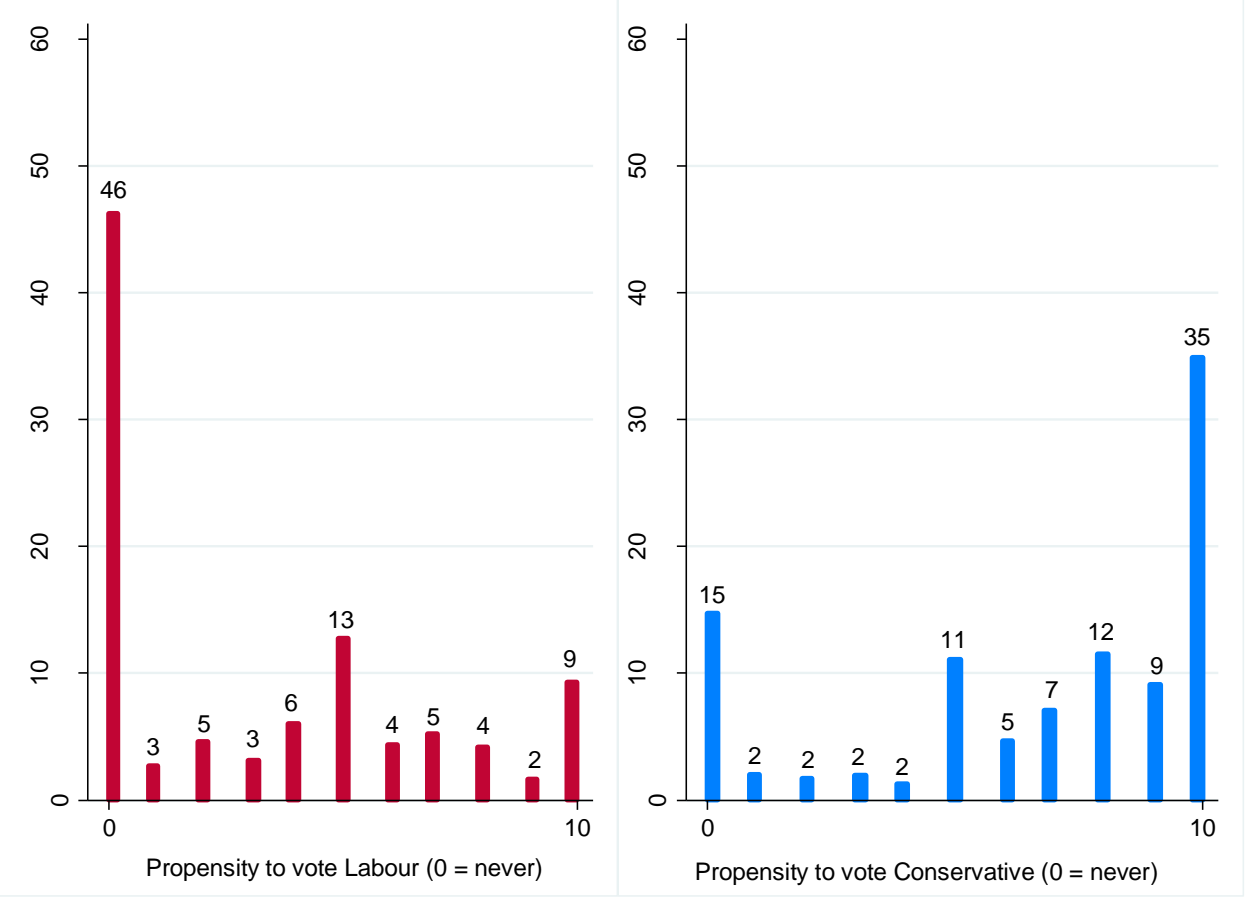
Like/dislike [Party leader] (Jewish Sample, $n=512$ )
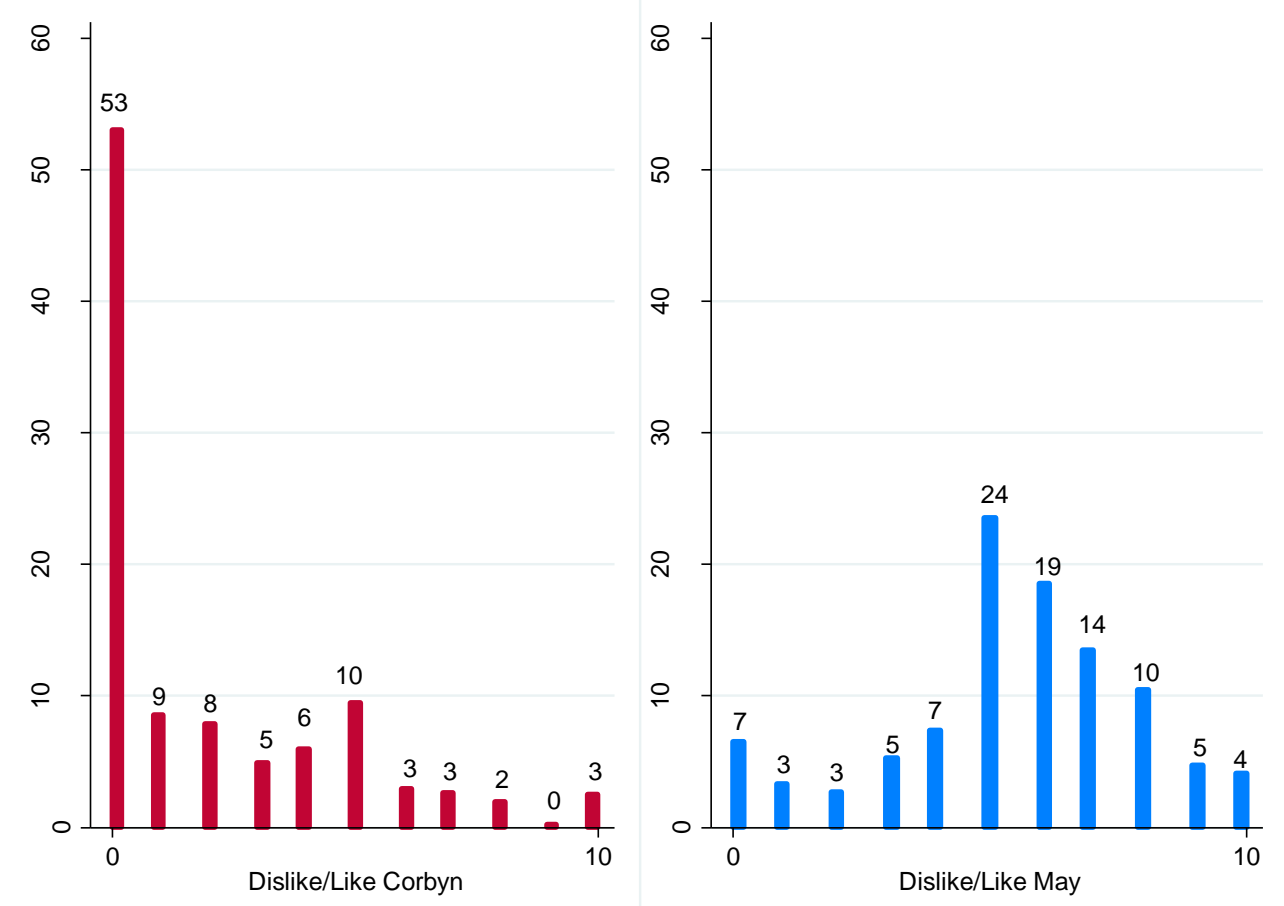

\section{Descriptive Results (British Election Study Comparisons)}

Propensity to vote for [Party] (British Election Study Wave 13, $n=31,196$ )
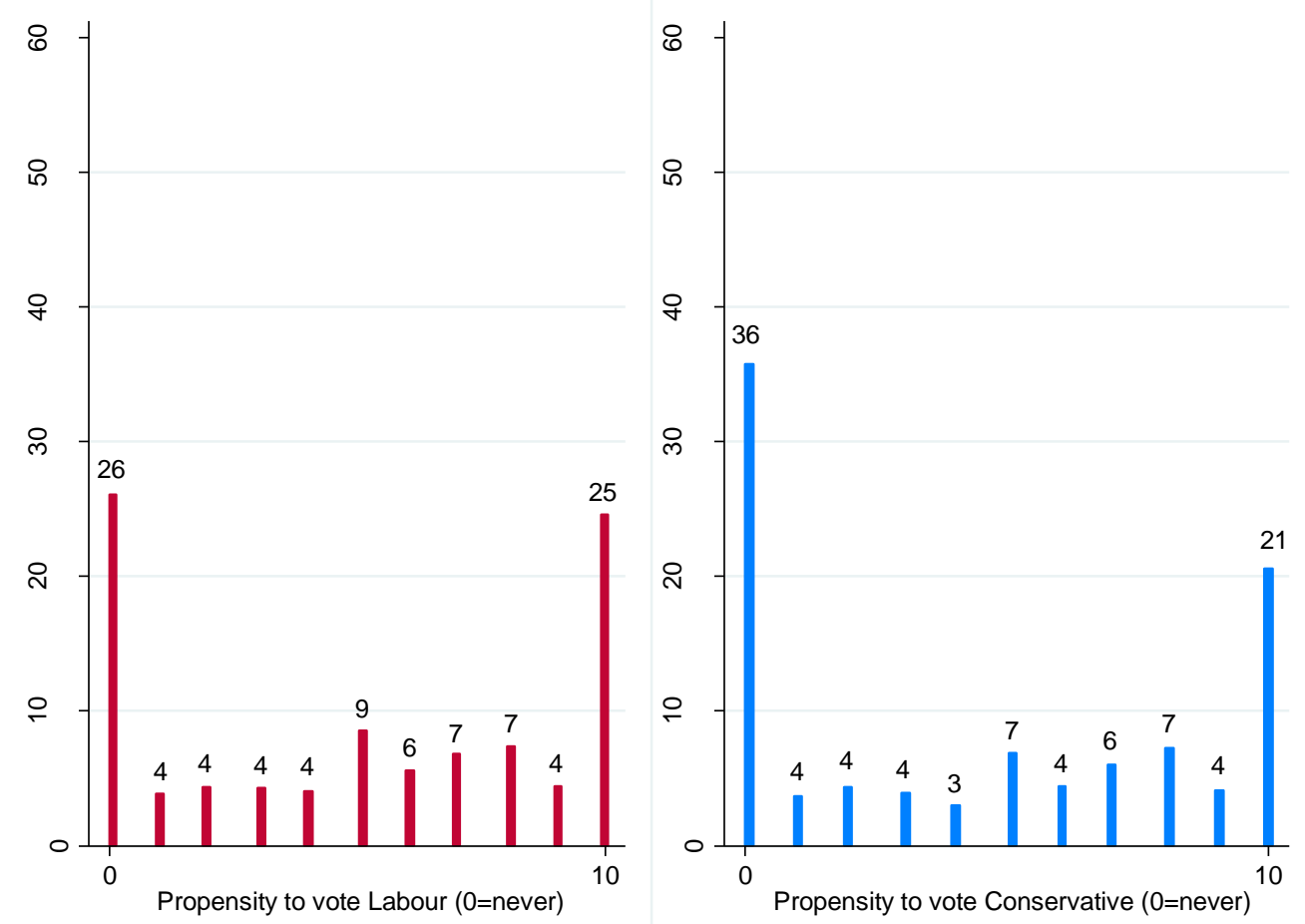

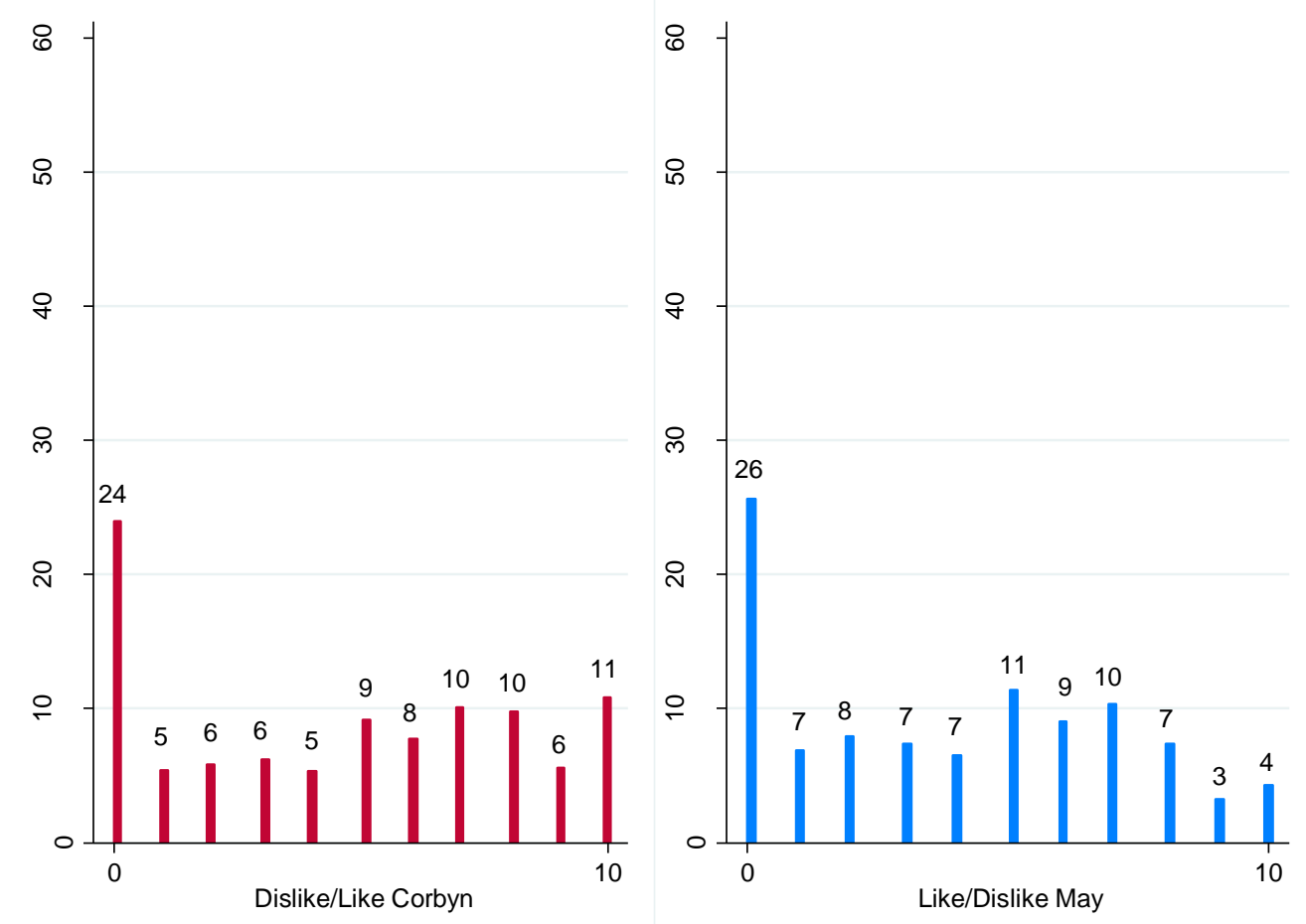

Net agree scores Jews/Non-Whites are held back by prejudice and discrimination (Jewish Sample $n=512$, Non-white Sample $n=2,657$, General Population Sample $n=3,328$ )

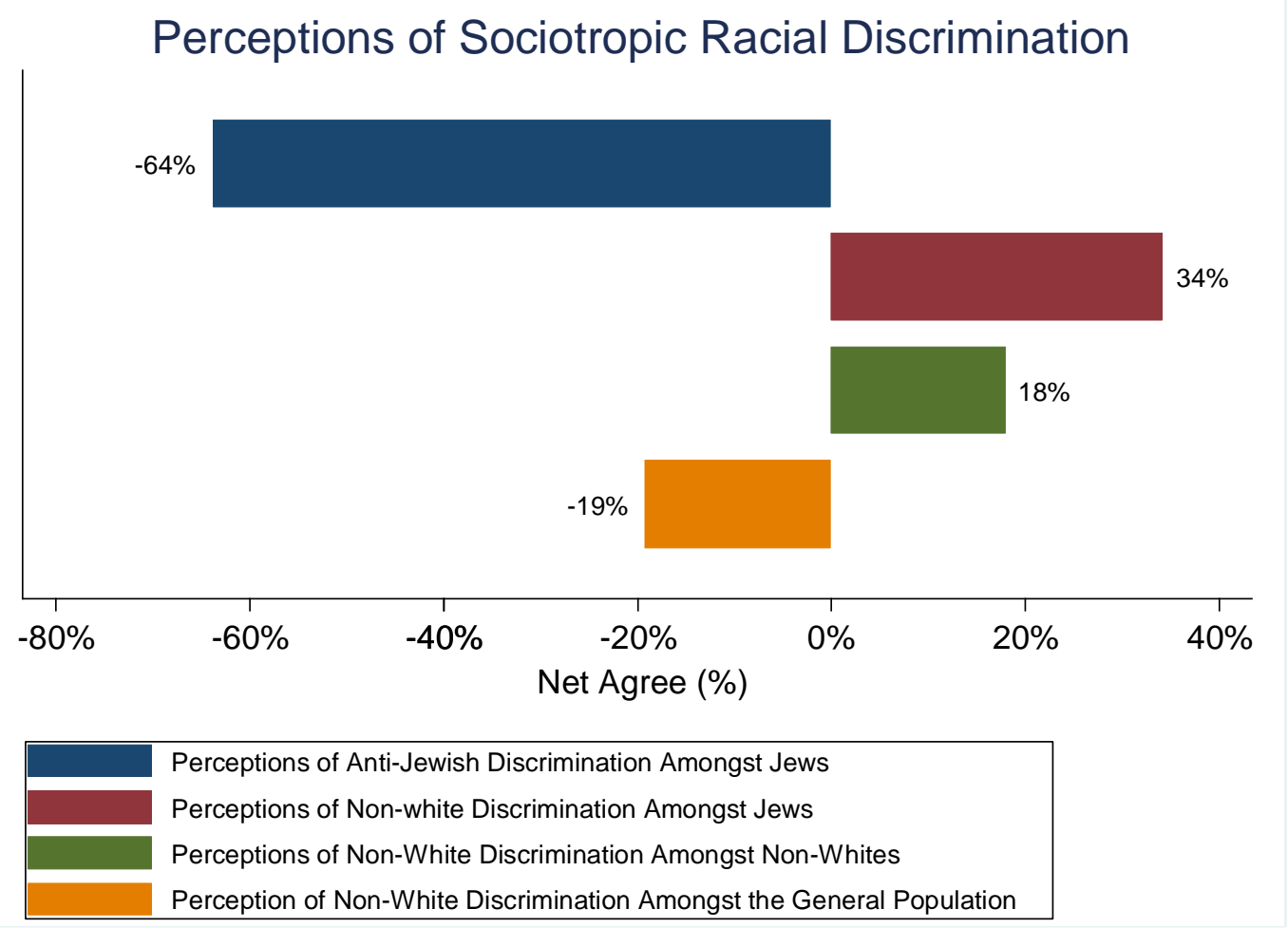


Any agree scores of Jews/Non-whites are held back by prejudice and discrimination amongst Jews, Non-whites broken down by ethnicity \& the general population (Jewish Sample $n=512$, General Population Sample $n=3,328$ Indian Sample $n=587$, Pakistani Sample $n=668$, Bangladeshi Sample $n=270$, Black Caribbean Sample $n=597$, Black African Sample $n=524$ )

\begin{tabular}{|l|c|c|}
\hline & $\begin{array}{c}\text { Jews are held back in } \\
\text { Society by Prejudice } \\
\text { (Any agree \%) }\end{array}$ & $\begin{array}{c}\text { Non-whites are held } \\
\text { back in Society by } \\
\text { Prejudice (Any agree \%) }\end{array}$ \\
\hline Jewish & 16 & 63 \\
\hline General Population & - & 31 \\
\hline Indian & - & 43 \\
\hline Pakistani & - & 39 \\
\hline Bangladeshi & - & 47 \\
\hline Black Caribbean & - & 58 \\
\hline Black African & - & 55 \\
\hline
\end{tabular}

British Election Study Voting Intention: Jewish voters vs General Population

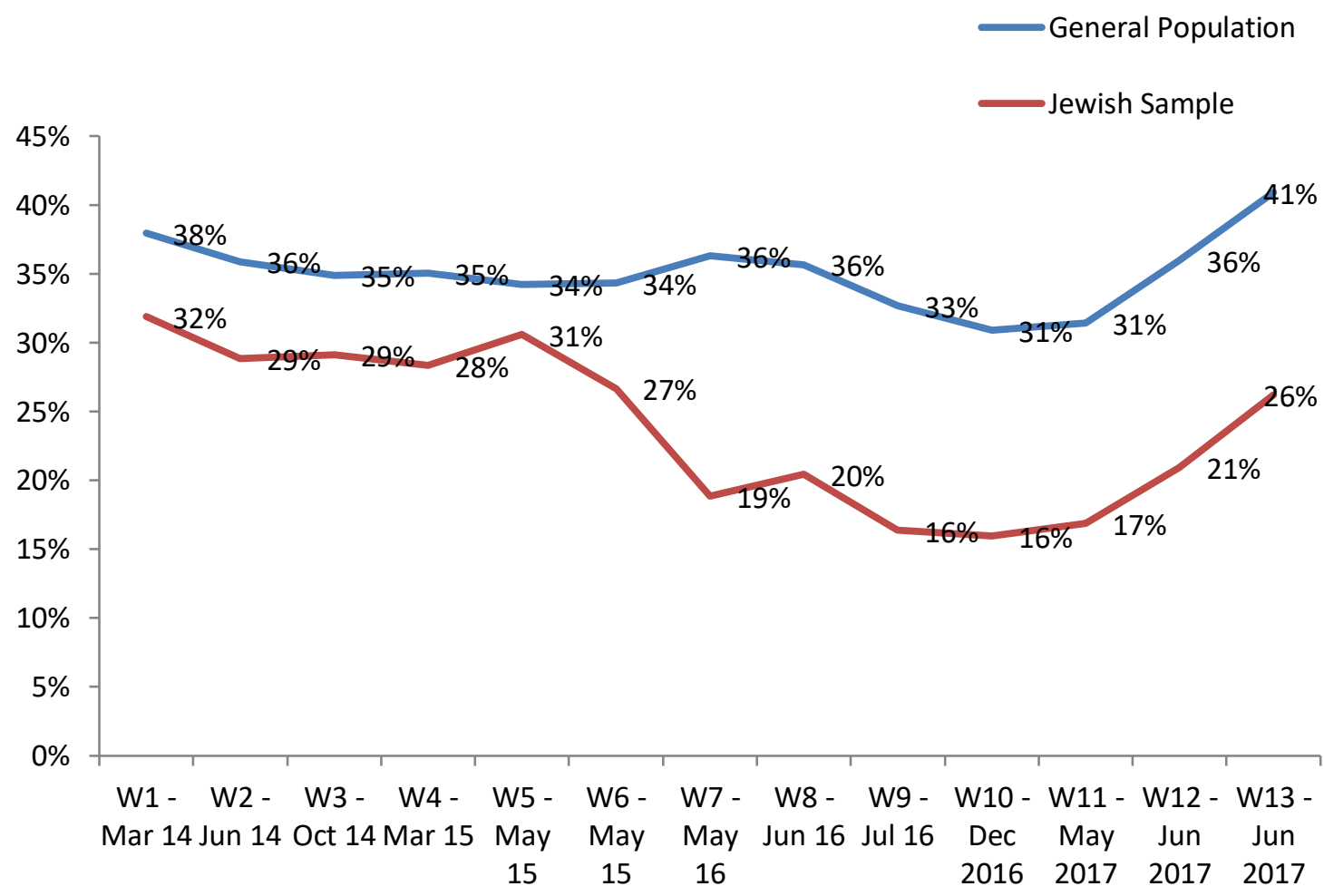




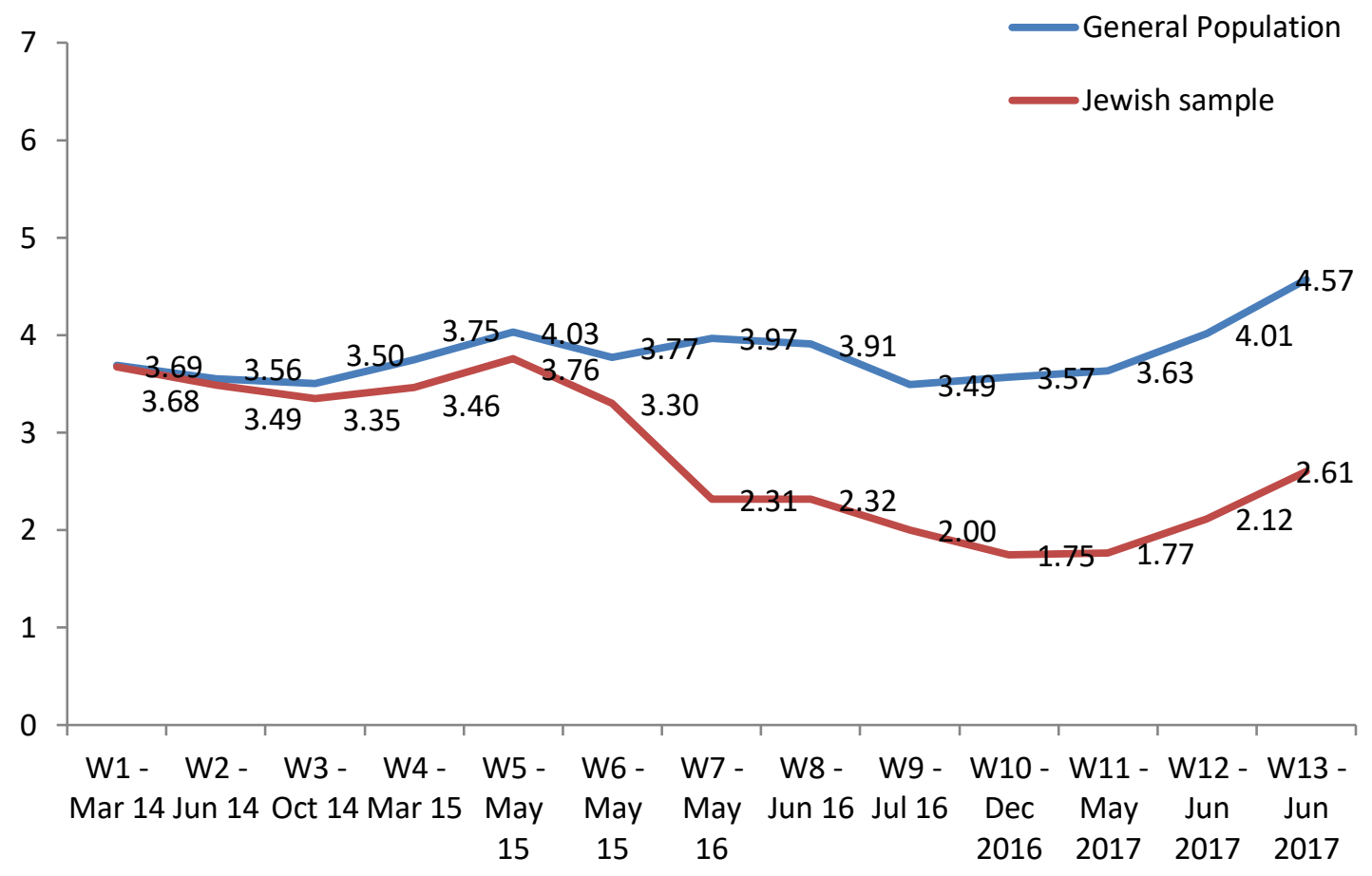

\section{Marginal Effects Predictions of Propensity to Vote}

Marginal effects of Corbyn Evaluation on Propensity to Vote Labour (Jewish Sample $n=512$ General Population Sample $n=31,196$ )

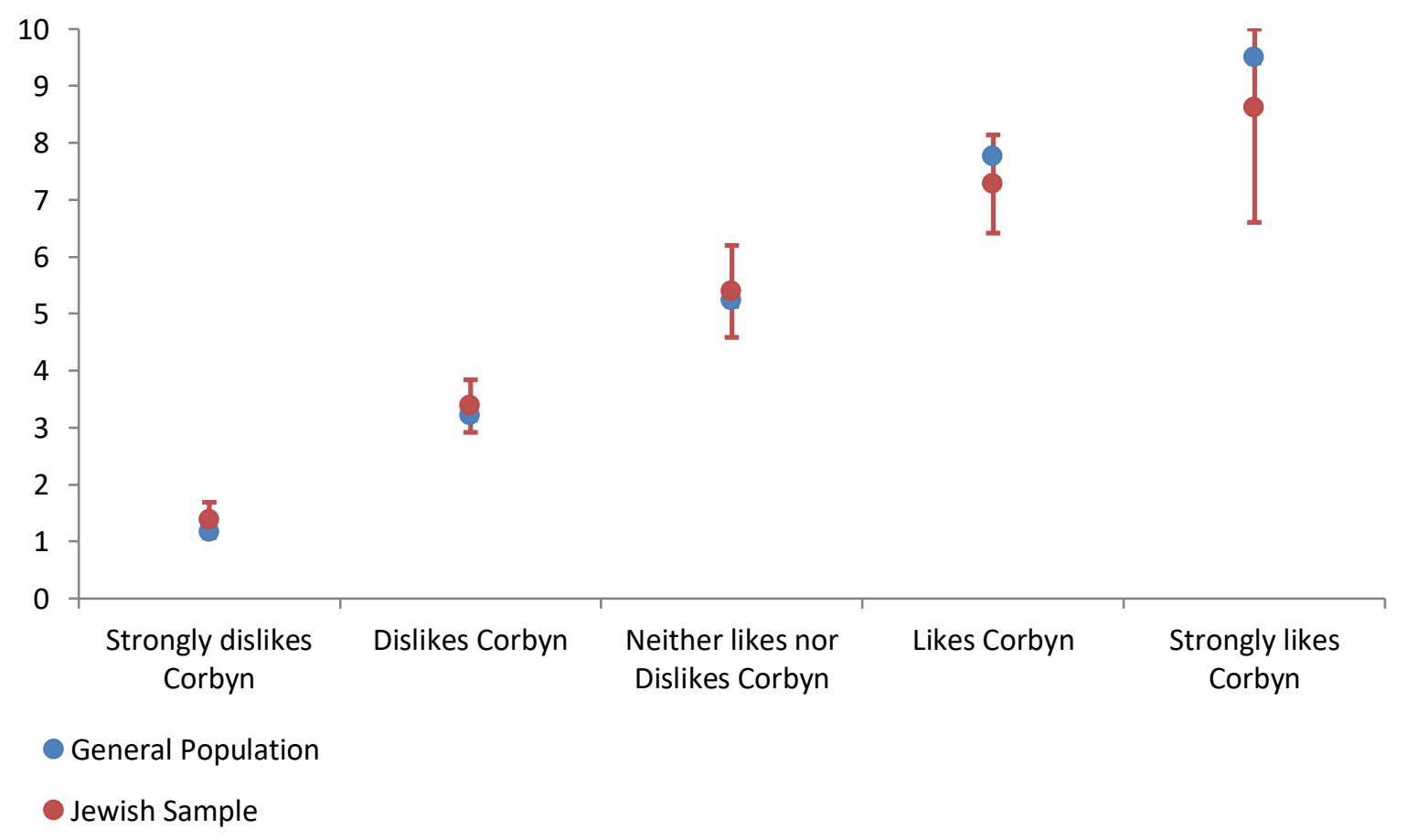


Marginal effects of Propensity to Vote Conservative on May Evaluation on Propensity to Vote Conservative (Jewish Sample $n=512$ General Population Sample $n=3,328$ )

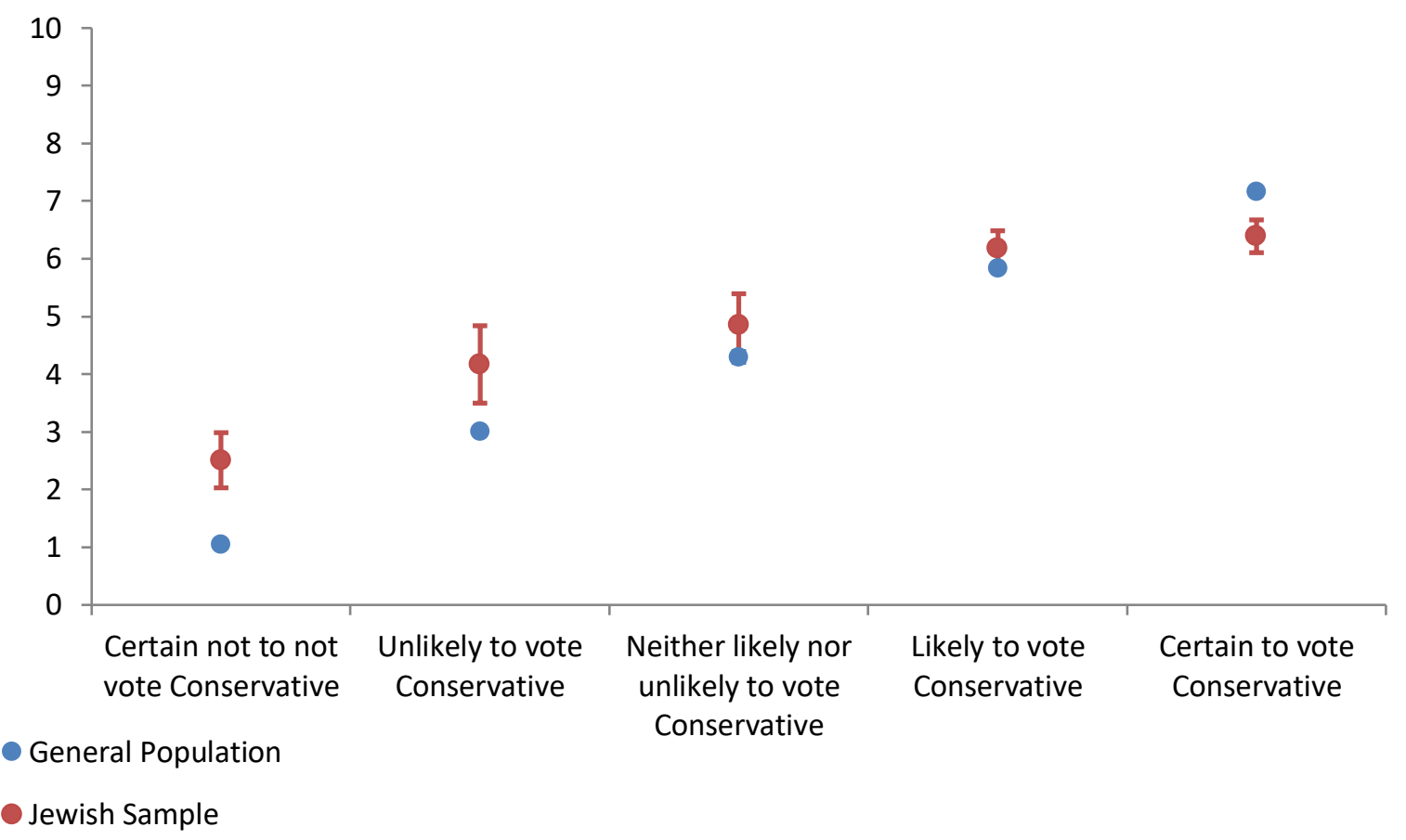

